\title{
Kinetic Study of Singlet-Oxygen Quenching and Aroxyl-Radical Scavenging Activities of Vitamin E Homologs and Fatty Acids Present in Vegetable Oils
}

\author{
Kazuo Mukai $^{1 *}$, Masayuki Hirata ${ }^{1}$, Junya Ito $^{2}$, Taiki Shiomi ${ }^{2}$, Kiyotaka Nakagawa ${ }^{2}$, and \\ Shin-ichi Nagaoka ${ }^{1}$

\footnotetext{
${ }^{1}$ Department of Chemistry, Faculty of Science, Ehime University, Bunkyo-cho 2-5, Matsuyama 790-8577, JAPAN

${ }^{2}$ Food and Biodynamic Chemistry Laboratory, Graduate School of Agricultural Science, Tohoku University, 1 - 1 Tsutsumidori-Amamiyamachi, Aobaku, Sendai 981-8555, JAPAN
}

\begin{abstract}
Recently, singlet-oxygen $\left({ }^{1} \mathrm{O}_{2}\right)$ quenching and aroxyl-radical (ArO $)$ scavenging rates $\left(k_{\mathrm{Q}}\right.$ and $k_{\mathrm{S}}$, respectively) of eight vegetable oils were measured in the ethanol/chloroform/ $/ \mathrm{D}_{2} \mathrm{O}$ solution. Furthermore, the $k_{\mathrm{Q}}$ and $k_{\mathrm{S}}$ values and concentrations of four tocopherols and four tocotrienols contained in the vegetable oils were measured. In this study, the concentrations of nine fatty acids (including stearic, oleic, linoleic, and linolenic acids) comprising the above-mentioned eight vegetable oils were determined by gas chromatography. The $k_{\mathrm{Q}}$ and $\boldsymbol{k}_{\mathrm{S}}$ values for ethyl stearate, ethyl oleate, ethyl linoleate, methyl linolenate, and glyceryl trioleate in the ethanol/chloroform/ $/ \mathrm{D}_{2} \mathrm{O}$ solution were measured by $\mathrm{UV}$-vis spectrophotometry. Based on the results obtained for the above-mentioned fatty acid esters, the $k_{\mathrm{O}}$ and $\boldsymbol{k}_{\mathrm{S}}$ values were estimated for nine fatty acids. Furthermore, comparisons of $k_{\mathrm{Q}}$ values observed for the vegetable oils with the sum of the product $\left\{\sum k_{\mathrm{Q}}{ }^{\mathrm{AO}-i}\right.$ [AO- $\left.\left.i\right]\right\}$ of the $k_{\mathrm{Q}}{ }^{\mathrm{AO}-i}$ values obtained for each antioxidant- $i$ (AO- $\left.i\right)$ and the concentrations ([AO-i]) of AO-i (i.e., four tocopherols ( $\&$ four tocotrienols) and nine fatty acids) contained in vegetable oils were performed. Based on the results, a detailed comparison of the contributions of the tocopherols (and tocotrienols) and the fatty acids to the ${ }^{1} \mathrm{O}_{2}$-quenching rate constants $\left(k_{\mathrm{O}}\right)$ was performed. This indicated that both the tocopherols (and tocotrienols) and the fatty acids contribute to the ${ }^{1} \mathrm{O}_{2}$ quenching. A similar comparison was conducted for the ArO - -scavenging rate constants $\left(k_{\mathrm{s}}\right)$. The results suggested that only the tocopherols (and tocotrienols) contained in the oils contributed to the ArO• -scavenging, with negligible contribution from the fatty acids.
\end{abstract}

Key words: vegetable oils, singlet oxygen, aroxyl radical, antioxidant activity, tocopherol and tocotrienol, fatty acid, kinetic study

\section{Introduction}

In recent years, reactive oxygen species (ROS) have attracted much attention, because various disorders and diseases are induced by the oxidative stress generated by them ${ }^{1)}$. Singlet oxygen $\left({ }^{1} \mathrm{O}_{2}\right)$ and lipid peroxyl radical (LOO·) are well-known representative ROS generated in biological systems. ${ }^{1} \mathrm{O}_{2}$ and $\mathrm{LOO} \cdot$ react with numerous types of biological molecules such as lipids ${ }^{2-5)}$, proteins ${ }^{6)}$, and $\mathrm{DNA}^{7,8)}$, inducing the degradation of biological systems. Carotenoids and vitamin E homologs $(\alpha-, \beta-, \gamma-$, and $\delta$-tocopherols (-Tocs) and -tocotrienols (-Toc-3s)) are widely present in vegetables, fruits, and edible oils ${ }^{9-14}$ and may function as antioxidants (AOs) by quenching ${ }^{1} \mathrm{O}_{2}$ and/ or scavenging $\mathrm{LOO} \cdot{ }^{14-21)}$

Recently, kinetic studies of the quenching reaction of ${ }^{1} \mathrm{O}_{2}$ with natural AOs were performed in ethanol/chloroform/ $\mathrm{D}_{2} \mathrm{O}(50: 50: 1, \mathrm{v} / \mathrm{v} / \mathrm{v})$ (hereafter called as "mixed solvent" for the simplicity) and ethanol at $35^{\circ} \mathrm{C}^{22-25)}$. The overall rate constants, $k_{\mathrm{Q}}\left(=k_{\mathrm{q}}+k_{\mathrm{r}}\right.$, physical quenching + chemical reaction), for the reactions of the AOs with ${ }^{1} \mathrm{O}_{2}$ were measured using a competition reaction method with endoperoxide (EP) (i.e., 3-(1,4-epidioxy-4-methyl-1,4-dihydro1-naphthyl) propionic acid) as a ${ }^{1} \mathrm{O}_{2}$ generator and 2,5-diphenyl-3,4-benzofuran (DPBF) as an UV-vis absorption probe (Scheme 1) ${ }^{23)}$.

\footnotetext{
*Correspondence to: Kazuo Mukai, Department of Chemistry, Faculty of Science, Ehime University, Bunkyo-cho 2-5, Matsuyama 790-8577, JAPAN

E-mail: mukai-k@dpc.ehime-u.ac.jp

Accepted October 26, 2019 (received for review August 30, 2019)

Journal of Oleo Science ISSN 1345-8957 print / ISSN 1347-3352 online

http://www.jstage.jst.go.jp/browse/jos/ http://mc.manusriptcentral.com/jjocs
} 

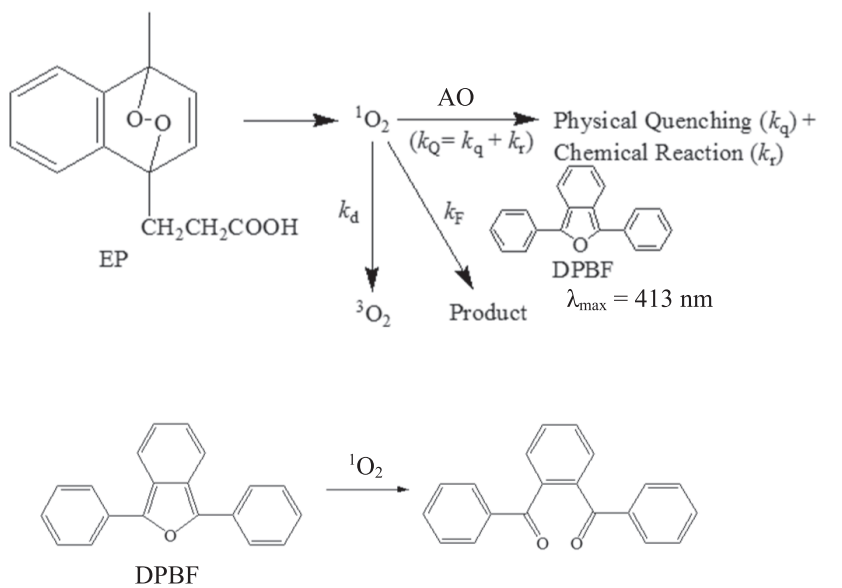

\section{Scheme 1}

$$
{ }^{1} \mathrm{O}_{2}+\mathrm{AO} \rightarrow \text { physical quenching }\left(k_{\mathrm{q}}\right)+\text { chemical reaction }\left(k_{\mathrm{r}}\right)
$$

The second-order rate constants, $k_{Q}(S)$ and $k_{Q}\left(t_{1 / 2}\right)$, were determined by analyzing the first-order rate constant $(S)$ and half-life $\left(t_{1 / 2}\right)$ of the decay curve of DPBF, respectively. Measurements of the $k_{Q}(\mathrm{~S})$ and $k_{Q}\left(t_{1 / 2}\right)$ values were performed not for only natural AOs, but also for numerous food and plant extracts ${ }^{14,25)}$. From the results, a new assay method that could quantify the singlet oxygen absorption capacities (SOAC) of the natural AOs and food extracts was proposed $^{22-25)}$.

Edible vegetable oils are used for cooking in ordinary homes daily. As vegetable oils contain high concentrations of unsaturated lipids, they are exposed to risk of lipid peroxidation $^{12,17,26)}$. Therefore, vitamin $\mathrm{E}$ homologs are includ- ed in vegetable oils, to prevent the peroxidation of the unsaturated lipids ${ }^{12,17,27-29)}$. However, a detailed kinetic study to evaluate the $\mathrm{AO}$ activities of vegetable oils has not been performed.

In a previous study, the ${ }^{1} \mathrm{O}_{2}$-quenching rates $\left(k_{\mathrm{Q}}\right)$ and the SOAC values were measured for eight vegetable oils (numbered 1 - 8) in mixed solvent via UV-vis spectrophotome$\operatorname{try}^{30)}$. The $k_{\mathrm{Q}}{ }^{\text {Oil }}(S)$ (Obsd.) values obtained for oils $1-8$ are listed in Table 1. The contents of the $\alpha-, \beta-, \gamma$, and $\delta$-Tocs and -Toc-3s contained in oils $1-8$ were determined (see supplementaruy Table S1) ${ }^{29}$. Furthermore, comparisons of the $k_{\mathrm{Q}}{ }_{\mathrm{Q}}^{\text {oil }}(S)$ (Obsd.) values observed for the above oils 1 8 with the $k_{\mathrm{Q}}{ }^{\text {Toc }(\text { Toc-3) }}(S)$ (Calcd.) values (i.e., the sum of the product $\left\{\sum k_{\mathrm{Q}}{ }^{\mathrm{AO}-i}[\mathrm{AO}-i]\right\}$ of the $k_{\mathrm{Q}}{ }^{\mathrm{AO}-i}$ values obtained for each $\mathrm{AO}-i$ and the concentration ( $[\mathrm{AO}-i]$ ) of $\mathrm{AO}-i$ (i.e., four Tocs (and four Toc-3s) ) contained in oils $1-8)$ were performed. In Table 1, $k_{Q}(S)$ (Obsd.) and $k_{Q}(S)$ (Calcd.) are abbreviated as $k_{Q}\left(\right.$ Obsd.) and $k_{Q}$ (Calcd.), respectively, for the simplicity. As listed in Table 1, the ratio of the rate con$\operatorname{stants}\left(k_{\mathrm{Q}}{ }^{\text {Toc(\& Toc-3) }}\right.$ (Calcd.) $/ k_{Q}{ }_{\mathrm{Q}}^{\text {Oil }}$ (Obsd. $\left.)\right)$ varied from 0.175 for olive oil 7 to 0.542 for safflower oil 8. The $k_{Q}{ }^{\text {oil }}$ (Obsd.) values are not explained by the $k_{\mathrm{Q}}{ }^{\text {Toc } \& \text { Toc-3) }}$ (Calcd.) values calculated using only the concentrations of the four Tocs (and four Toc-3s). As high concentrations of fatty acids are contained in vegetable oils ${ }^{12,17,26)}$, it may be necessary to consider their contribution to explain the $k_{Q}{ }^{\text {Oil }}$ (Obsd.) values.

Recently, the second-order rate constants $\left(k_{\mathrm{S}}{ }^{\text {oil }}\right)$ for the reaction of eight vegetable oils 1 - 8 with 2,6-di-t-butyl-4(4-methoxyphenyl) phenoxyl (abbreviated as aroxyl $(\mathrm{ArO} \cdot))$ radical (Fig. 1) were measured in mixed solvent (Table 2), in order to clarify the free radical-scavenging

Table 1 Comparison between observed and calculated ${ }^{1} \mathrm{O}_{2}$-quenching rate constants $\left(k_{Q}{ }^{\text {oil }}(\right.$ Obsd. $)$ and $k_{Q}($ Calcd. $\left.)\right)$ for eight

\begin{tabular}{|c|c|c|c|c|c|c|c|}
\hline & $\begin{array}{c}\text { Reaction of } \\
{ }^{1} \mathrm{O}_{2} \text { with Oils } \\
1-8\end{array}$ & $\begin{array}{l}\text { Reaction of } \\
{ }^{1} \mathrm{O}_{2} \text { with Tocs } \\
\text { (\& Toc-3s) }\end{array}$ & $\begin{array}{c}\text { Ratio } \\
\text { (Contribution of Tocs } \\
(\& \text { Toc-3s }))\end{array}$ & $\begin{array}{c}\text { Reaction of } \\
{ }^{1} \mathrm{O}_{2} \text { with Acids }\end{array}$ & $\begin{array}{c}\text { Ratio } \\
\text { (Contribution of } \\
\text { Acids) }\end{array}$ & $\begin{array}{l}\text { Reaction of }{ }^{1} \mathrm{O}_{2} \\
\text { with Tocs (\& Toc- } \\
\text { 3s) and Acids }\end{array}$ & $\begin{array}{c}\text { Ratio (Contribution } \\
\text { of Tocs (\& Toc-3s) } \\
\text { and Acids) }\end{array}$ \\
\hline \multirow[t]{2}{*}{ Vegetable oil } & $k_{\mathrm{Q}}^{\mathrm{Oil}}(\text { Obsd. })^{\mathrm{a}}$ & $\begin{array}{l}k_{\mathrm{Q}}^{T b c(\& T o c-3)} \\
(\text { Calcd. })^{\mathrm{a}, \mathrm{b}}\end{array}$ & $\begin{array}{c}k_{\mathrm{Q}}^{T b c(\& T o c-3)}(\text { Calcd. })^{\mathrm{b}} / \\
k_{\mathrm{Q}}^{\text {Oil }} \text { (Obsd.) }\end{array}$ & $\begin{array}{c}k_{\mathrm{Q}}^{\text {Acid }} \\
(\text { Calcd. })^{\mathrm{a}, \mathrm{c}}\end{array}$ & $\begin{array}{l}k_{\mathrm{Q}}^{\text {Acid }}(\text { Calcd. })^{\mathrm{c}} \\
k_{\mathrm{Q}}{ }^{\text {Oil }} \text { (Obsd.) }\end{array}$ & $k_{\mathrm{Q}}^{\text {Total }}(\text { Calcd. })^{\mathrm{a}, \mathrm{d}}$ & $\begin{array}{c}k_{\mathrm{Q}}^{\text {Total }}(\text { Calcd. })^{\mathrm{d}} \\
k_{\mathrm{Q}}^{\text {Oil }}(\text { Obsd. })\end{array}$ \\
\hline & $\mathrm{Lg}^{-1} \mathrm{~s}^{-1}$ & $\mathrm{Lg}^{-1} \mathrm{~s}^{-1}$ & & $\mathrm{Lg}^{-1} \mathrm{~s}^{-1}$ & & $\mathrm{Lg}^{-1} \mathrm{~s}^{-1}$ & \\
\hline Rice bran oil 1 & $7.69 \times 10^{2}$ & $2.58 \times 10^{2}$ & 0.336 & $1.02 \times 10^{2}$ & 0.133 & $3.59 \times 10^{2}$ & 0.467 \\
\hline Sesame oil 2 & $4.61 \times 10^{2}$ & $1.16 \times 10^{2}$ & 0.252 & $1.11 \times 10^{2}$ & 0.241 & $2.27 \times 10^{2}$ & 0.492 \\
\hline Perilla oil 3 & $4.49 \times 10^{2}$ & $1.54 \times 10^{2}$ & 0.343 & $1.44 \times 10^{2}$ & 0.321 & $2.98 \times 10^{2}$ & 0.664 \\
\hline Grape seed oil 4 & $3.94 \times 10^{2}$ & $1.11 \times 10^{2}$ & 0.282 & $1.09 \times 10^{2}$ & 0.277 & $2.20 \times 10^{2}$ & 0.558 \\
\hline Rape seed oil 5 & $3.79 \times 10^{2}$ & $1.43 \times 10^{2}$ & 0.377 & $1.17 \times 10^{2}$ & 0.309 & $2.60 \times 10^{2}$ & 0.686 \\
\hline Extra virgin olive oil 6 & $3.28 \times 10^{2}$ & $7.97 \times 10$ & 0.243 & $1.14 \times 10^{2}$ & 0.348 & $1.93 \times 10^{2}$ & 0.588 \\
\hline Olive oil 7 & $3.00 \times 10^{2}$ & $5.26 \times 10$ & 0.175 & $1.09 \times 10^{2}$ & 0.363 & $1.61 \times 10^{2}$ & 0.537 \\
\hline Safflower oil 8 & $2.77 \times 10^{2}$ & $1.50 \times 10^{2}$ & 0.542 & $1.05 \times 10^{2}$ & 0.379 & $2.55 \times 10^{2}$ & 0.921 \\
\hline$\alpha$-Tocopherol & $3.04 \times 10^{5}$ & & 1.00 & & & & \\
\hline
\end{tabular}
vegetable oils $1-8$ in ethanol/chloroform $/ \mathrm{D}_{2} \mathrm{O}$ solution, and ratio of the rate constants $\left(k_{Q}(\right.$ Calcd. $) / k_{Q}{ }_{Q}$ iil $($ Obsd. $\left.)\right)$.

${ }^{\mathrm{a}} k_{\mathrm{Q}}(S)$ (Obsd.) and $k_{\mathrm{Q}}(S)$ (Calcd.) were abbreviated as $k_{\mathrm{Q}}$ (Obsd.) and $k_{\mathrm{Q}}$ (Calcd.), respectively, for the simplicity.

${ }^{\mathrm{b}} \mathrm{The} k_{\mathrm{Q}}{ }^{\text {Toc (\& Toc-3) }}$ (Calcd.) values calculated for total Tocs and Toc-3s.

${ }^{\mathrm{c}}$ The $k_{\mathrm{Q}}{ }^{\text {Acid }}$ (Calcd.) values calculated for total fatty acids $1-9$.

${ }^{\mathrm{d}}$ The $k_{\mathrm{Q}}{ }^{\text {Total }}$ (Calcd.) values calculated for total Tocs, Toc-3s and fatty acids. 


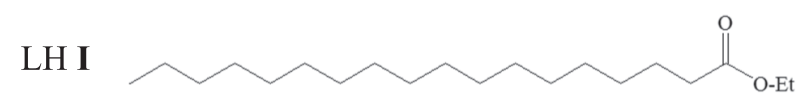

$\mathrm{LH}$ II

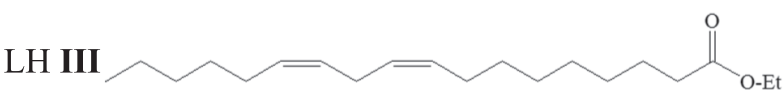

$\mathrm{LHIV}$

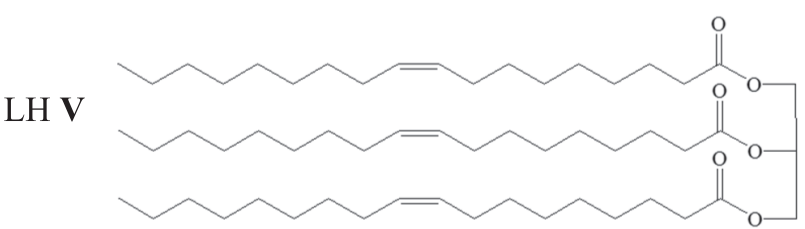

$C_{C}^{\mathrm{C}_{16} \mathrm{H}_{33}}$

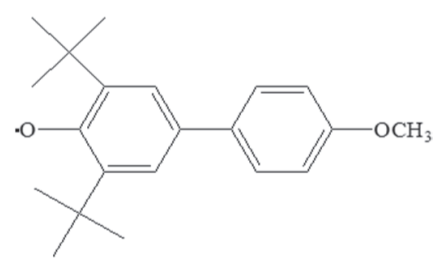

$\alpha-$ Toc

$\mathrm{ArO} \cdot$

Fig. 1 Molecular structures of five fatty acid esters (LH I V) (ethyl stearate I, ethyl oleate II, ethyl linoleate III, methyl linolenate IV, and glyceryl trioleate V), $\alpha$-tocopherol $(\alpha-\mathrm{TocH})$, and aroxyl $\operatorname{radical}(\mathrm{ArO} \cdot)$. activities of vegetable oils $1-8^{29)}$.

$$
\underset{k_{\mathrm{S}}}{\mathrm{ArO} \cdot+\mathrm{AO} \rightarrow \mathrm{ArOH}+\mathrm{AO} \cdot}
$$

As the amounts of the $\alpha-, \beta-, \gamma-, \delta$-Tocs and -Toc-3s contained in vegetable oils $1-8$ are different, different $\mathrm{ArO}$. radical-scavenging activities are observed for oils $1-8^{29)}$. For example, rice bran oil 1 showed 8.0 times larger $k_{\mathrm{S}}{ }^{\text {oil }}$ (Obsd.) value than that of olive oil 7 (Table 2). As reported in a previous study ${ }^{29)}$ and described subsequently in Sec. 4.2., the $k_{\mathrm{S}}{ }^{\text {Oil }}$ (Obsd.) values for oils 1 - 8 are well explained by the $k_{\mathrm{S}}{ }^{\text {Toc(\& Toc-3) }}$ (Calcd.) values calculated using the $k_{\mathrm{S}}{ }^{\mathrm{AO}-i}$ values (AO- $i$ : four Tocs (and four Toc-3s) ) and concentrations of the four Tocs (and four Toc-3s) contained in oils 1 8 (Table 2).

As described in previous studies ${ }^{31-33)}$, ArO $\cdot$ can be regarded as a model for the active oxygen radicals ( $\mathrm{LOO} \cdot$ and others) found in foods and biological systems. For example, the second-order rate constants $\left(k_{\mathrm{S}}\right)$ obtained in ethanol at $25.0^{\circ} \mathrm{C}$ were $5.12 \times 10^{3}$ ( $\alpha$-Toc), $2.24 \times 10^{3}$ ( $\beta$-Toc), $2.42 \times$ $10^{3}(\gamma$-Toc $)$ and $1.00 \times 10^{3}(\delta$-Toc $) \mathrm{M}^{-1} \mathrm{~s}^{-1}$. The relative rates ( $\alpha: \beta: \gamma: \delta=100: 44: 47: 20$ ) agreed well with those obtained in the studies on the reactivity of Tocs toward the poly (peroxystyryl) peroxyl radicals (100:41:44:14) in chlorobenzene using the $\mathrm{O}_{2}$ consumption method ${ }^{15)}$. The above results suggest that the relative reactivities of Tocs in solution probably does not depend on the type of the oxyradicals $(\mathrm{ArO} \cdot$ and $\mathrm{LOO} \cdot$ ) used.

In the present study, first, concentrations of nine fatty acids $1-9(i . e .,[\operatorname{Acid}-i(i=1-9)])$ contained in vegetable oils 1 - 8 were determined, via gas chromatography $(\mathrm{GC})^{34,35)}$. Second, measurements of the rate constants $\left(k_{\mathrm{Q}}{ }^{\mathrm{LH}}(\mathrm{S})\right.$ and

Table 2 Comparison between observed and calculated ArO $\cdot$-scavenging rate constants $\left(k_{\mathrm{S}}\left(\right.\right.$ Obsd.) and $k_{\mathrm{S}}($ Calcd. $\left.)\right)$ for eight vegetable oils $1-8$ in ethanol/chloroform $/ \mathrm{D}_{2} \mathrm{O}$ solution, and ratio of the rate constants $\left(k_{\mathrm{S}}(\mathrm{Calcd}\right.$. $) /$

\begin{tabular}{|c|c|c|c|c|c|}
\hline & $\begin{array}{c}\text { Reaction of } \mathrm{ArO} \cdot \text { with } \\
\text { Oils } 1-8\end{array}$ & $\begin{array}{c}\text { Reaction of ArO } \cdot \text { with } 4 \\
\text { Tocs }(\& 4 \text { Toc-3s) }\end{array}$ & $\begin{array}{l}\text { Ratio (Contribution of } 4 \\
\text { Tocs (\& } 4 \text { Toc-3s)) }\end{array}$ & $\begin{array}{c}\text { Reaction of } \mathrm{ArO} \cdot \text { with } 9 \\
\text { Fatty Acids }\end{array}$ & $\begin{array}{c}\text { Ratio (Contribution of } 9 \\
\text { Fatty Acids) }\end{array}$ \\
\hline \multirow[t]{2}{*}{ Vegetable oil } & $k_{\mathrm{S}}^{\text {Oil }}$ (Obsd.) & $k_{\mathrm{S}}^{\mathrm{Toc}(\& \text { Toc-3) }}(\text { Calcd. })^{\mathrm{a}}$ & $\begin{array}{c}k_{\mathrm{S}}^{\text {Toc }(\& \text { Toc-3) }}(\text { Calcd. }) \\
/_{k_{\mathrm{S}}}^{\text {Oil }}(\text { Obsd. })\end{array}$ & $k_{\mathrm{S}}^{A c i d}(\text { Calcd. })^{\mathrm{b}}$ & $\begin{array}{c}k_{\mathrm{S}}^{\text {Acid }} \text { (Calcd.) } \\
/ k_{\mathrm{S}}^{\text {Oil }} \text { (Obsd.) }\end{array}$ \\
\hline & $\mathrm{Lg}^{-1} \mathrm{~s}^{-1}$ & $\mathrm{Lg}^{-1} \mathrm{~s}^{-1}$ & & $\mathrm{Lg}^{-1} \mathrm{~s}^{-1}$ & \\
\hline Rice bran oil 1 & $16.1 \times 10^{-3}$ & $14.4 \times 10^{-3}$ & 0.894 & $6.89 \times 10^{-7}$ & $4.28 \times 10^{-5}$ \\
\hline Sesame oil 2 & $6.05 \times 10^{-3}$ & $6.48 \times 10^{-3}$ & 1.07 & $7.74 \times 10^{-7}$ & $1.28 \times 10^{-4}$ \\
\hline Perilla oil 3 & $9.17 \times 10^{-3}$ & $8.66 \times 10^{-3}$ & 0.944 & $19.5 \times 10^{-7}$ & $2.13 \times 10^{-4}$ \\
\hline Grape seed oil 4 & $7.32 \times 10^{-3}$ & $6.25 \times 10^{-3}$ & 0.854 & $12.3 \times 10^{-7}$ & $1.68 \times 10^{-4}$ \\
\hline Rape seed oil 5 & $8.71 \times 10^{-3}$ & $8.01 \times 10^{-3}$ & 0.920 & $6.74 \times 10^{-7}$ & $7.74 \times 10^{-5}$ \\
\hline Extra virgin olive oil 6 & $4.86 \times 10^{-3}$ & $4.48 \times 10^{-3}$ & 0.922 & $2.69 \times 10^{-7}$ & $5.53 \times 10^{-5}$ \\
\hline Olive oil 7 & $2.02 \times 10^{-3}$ & $2.96 \times 10^{-3}$ & 1.47 & $3.13 \times 10^{-7}$ & $1.55 \times 10^{-4}$ \\
\hline Safflower oil 8 & $8.40 \times 10^{-3}$ & $8.41 \times 10^{-3}$ & 1.00 & $1.49 \times 10^{-7}$ & $1.77 \times 10^{-5}$ \\
\hline
\end{tabular}
$k_{\mathrm{S}}($ Obsd.) ). 
$\left.k_{\mathrm{Q}}^{\mathrm{LH}}\left(t_{1 / 2}\right)\right)$ were performed for five fatty acid esters (LH I V) (Fig. 1) in mixed solvent. Here, fatty acid esters I - IV were used as the models of fatty acids $1-9$, as described in Sec. 4.1. Third, comparison of the $k_{\mathrm{Q}}(S)$ (Obsd.) values observed for the above oils 1 - 8 with the sum of the product $\left\{\sum k_{\mathrm{Q}}{ }^{\text {Acid- } i}(S)\right.$ [Acid- $\left.\left.i\right] / 10^{2}\right\}$ of the $k_{\mathrm{Q}}{ }^{\text {Acid- } i}(S)$ value obtained for each fatty acid (Acid- $i$ ) and the concentration ([Acid- $i] / 10^{2}$ (g/100 g unit)) of Acid- $i$ contained in oils 1 8 was performed, in order to evaluate the contribution of fatty acids 1 - 9 to the ${ }^{1} \mathrm{O}_{2}$-quenching activity ${ }^{30)}$. Furthermore, measurements of the $\mathrm{ArO} \cdot$-scavenging rate constant $\left(k_{\mathrm{S}}\right)$ were performed for fatty acid esters I - IV. As high concentrations of fatty acids $1-9$ (i.e., total fatty acids 75.7 - $85.5 \mathrm{~g} / 100 \mathrm{~g}$ oil) are contained in vegetable oils $1-8$ (Table 3 ), these fatty acids 1 - 9 may also contribute to the ArO $\cdot$-scavenging of vegetable oils $1-8$.

\section{Materials and Methods}

\subsection{Materials}

The eight vegetable oils (rice bran oil 1, sesame oil 2, perilla oil 3, grape seed oil 4, rape seed oil 5, extra virgin olive oil 6, olive oil 7, and safflower oil 8(Table 1)) were purchased at local grocery stores in Sendai (Japan), and the concentrations of nine types of fatty acids $1-9$ contained in these oils were measured. Five types of fatty acid esters (ethyl stearate I, ethyl oleate II, ethyl linoleate III, methyl linolenate IV, and glyceryl trioleate V) (Fig. 1)were purchased from Sigma-Aldrich Chemical Co. (St. Louis, MO), and used as received. The reference standard mixture of fatty acid methyl esters was obtained from NUCHEK-PREP, Inc. (Elysian, MN).
DPBF was obtained from Tokyo Kasei Chemicals, Japan. EP was obtained from Wakenyaku Co. Ltd., Japan. The UV spectrum of EP indicated that commercially available EP includes 95\% EP and 5\% unreacted EP-precursor ${ }^{22)}$. The $\mathrm{ArO} \cdot$ radical was synthesized according to the method of Rieker et $a l^{36)}$.

\subsection{Measurements of the rate constants $\left(k_{\mathrm{Q}}\right.$ and $\left.k_{\mathrm{S}}\right)$ for fatty acid esters I - V}

Measurements of the ${ }^{1} \mathrm{O}_{2}$-quenching ${ }^{22-24,30)}$ and $\mathrm{ArO}$. -scavenging ${ }^{37)}$ rate constants $\left(k_{\mathrm{Q}}\right.$ and $\left.k_{\mathrm{S}}\right)$ for fatty acid esters I - V, respectively, were performed in mixed solvent, using a Shimadzu UV-vis spectrophotometer (UV-1800), equipped with a six-channel cell-positioner and an electron-temperature control unit(CPS-240A). Measurements of the $k_{\mathrm{Q}}$ and $k_{\mathrm{S}}$ values were performed at $35.0 \pm 0.5^{\circ} \mathrm{C}$ and $25.0 \pm 0.5^{\circ} \mathrm{C}$, respectively. The experimental errors in the rate constants $\left(k_{\mathrm{Q}}(S), k_{\mathrm{Q}}\left(t_{1 / 2}\right)\right.$, and $\left.k_{\mathrm{S}}\right)$ are listed in Table 4, as "mean $\pm \mathrm{SD}$ ".

\subsection{Analyses of the second-order rate constants $\left(k_{\mathrm{Q}}{ }^{\mathrm{AO}}(S)\right.$ and $\left.k_{\mathrm{Q}}{ }^{\mathrm{AO}}\left(t_{1 / 2}\right)\right)$}

Rate constant $k_{\mathrm{Q}}{ }^{\mathrm{AO}}(S)$ for the reaction of ${ }^{1} \mathrm{O}_{2}$ with an $\mathrm{AO}$ was determined by Eq. (3), as reported in previous studies $^{22-24,30)}$.

$$
S_{\text {blank }} / S_{\mathrm{AO}}=1+\left\{k_{\mathrm{Q}}^{\mathrm{AO}}(S)[\mathrm{AO}]\right\} / k_{\mathrm{d}}
$$

where $S_{\text {blank }}$ and $S_{\mathrm{AO}}$ are the slopes of the first-order plots (i.e., $\ln$ (Absorbance) vs time plots) of the disappearance of $\mathrm{DPBF}$ in the absence and presence of the $\mathrm{AO}$, respectively. $k_{\mathrm{d}}$ is the rate constant of the natural deactivation of ${ }^{1} \mathrm{O}_{2}$ in ethanol: chloroform: $\mathrm{D}_{2} \mathrm{O}\left(k_{\mathrm{d}}=3.03 \times 10^{4} \mathrm{~s}^{-1}\right)^{16)}$. Equation (3) indicates that the $k_{\mathrm{Q}}{ }^{\mathrm{AO}}(S)$ value can be obtained from

Table 3 Contents (average values $[\mathrm{AV}]$ ) of nine fatty acids 1 - 9 included in eight vegetable oils $1-8$.

\begin{tabular}{|c|c|c|c|c|c|c|c|c|c|c|c|}
\hline \multirow{3}{*}{ Fatty acid } & $\begin{array}{c}\text { Myristic acid } \\
1\end{array}$ & $\begin{array}{c}\text { Palmitic } \\
\text { acid } 2\end{array}$ & $\begin{array}{l}\text { Palmitoleic } \\
\text { acid } 3\end{array}$ & $\begin{array}{l}\text { Stearic } \\
\text { acid } 4\end{array}$ & $\begin{array}{l}\text { Oleic } \\
\text { acid } 5\end{array}$ & $\begin{array}{l}\text { Vaccenic } \\
\text { acid } 6\end{array}$ & $\begin{array}{l}\text { Linoleic } \\
\text { acid } 7\end{array}$ & $\begin{array}{c}\alpha \text {-Linolenic } \\
\text { acid } 8\end{array}$ & $\begin{array}{c}\text { Arachidic } \\
\text { acid } 9\end{array}$ & & \multirow{3}{*}{$\begin{array}{l}\text { Total fatty } \\
\text { acids }\end{array}$} \\
\hline & C14:0 & $\mathrm{C} 16: 0$ & C16:1 n-7 & C18:0 & C18:1 n-9 & $\mathrm{C} 18: 1 \mathrm{n}-7$ & C18:2 n-6 & $\mathrm{C} 18: 3 \mathrm{n}-3$ & $\mathrm{C} 20: 0$ & U.K. & \\
\hline & Mw 228.37 & 256.43 & 254.41 & 284.48 & 282.47 & 282.46 & 280.45 & 278.43 & 312.53 & & \\
\hline Vegetable oil & $(\mathrm{nmol} / \mathrm{mg} \text { oil })^{\mathrm{a}}$ & & & & & & & & & & $(\mathrm{g} / 100 \mathrm{~g} \text { oil })^{\mathrm{b}}$ \\
\hline Rice bran oil 1 & Av $8.18^{\mathrm{c}}$ & 464.66 & 4.64 & 47.33 & 1142.54 & 26.02 & 987.08 & 34.76 & 15.40 & 19.93 & 75.707 \\
\hline Sesame oil 2 & 1.41 & 213.54 & 3.85 & 116.74 & 1362.86 & 50.40 & 1005.52 & 108.13 & 15.48 & 15.70 & 80.541 \\
\hline Perilla oil 3 & 1.71 & 173.95 & 2.96 & 42.88 & 295.30 & 27.21 & 428.26 & 2022.32 & 0.00 & 15.80 & 83.223 \\
\hline Grape seed oil 4 & 1.20 & 196.10 & 1.50 & 108.96 & 462.12 & 21.55 & 1977.05 & 10.95 & 3.90 & 15.24 & 77.729 \\
\hline Rape seed oil 5 & 1.55 & 122.60 & 6.62 & 52.14 & 1806.43 & 89.85 & 581.12 & 262.81 & 39.71 & 17.33 & 83.251 \\
\hline $\begin{array}{l}\text { Extra virgin olive } \\
\text { oil } 6\end{array}$ & 0.00 & 319.65 & 10.89 & 69.51 & 2390.36 & 42.14 & 192.03 & 21.76 & 11.72 & 17.52 & 85.520 \\
\hline Olive oil 7 & 0.66 & 391.80 & 44.74 & 56.61 & 2034.26 & 86.27 & 295.64 & 17.34 & 6.54 & 13.68 & 81.688 \\
\hline Safflower oil 8 & 2.72 & 171.11 & 0.90 & 62.84 & 2531.01 & 20.57 & 2.19 & 7.97 & 8.63 & 14.17 & 78.888 \\
\hline $\begin{array}{l}\text { Total conc. of each } \\
\text { fatty acid }\end{array}$ & 17.43 & 2053.41 & 76.10 & 557.01 & 12024.88 & 364.01 & 5468.89 & 2486.04 & 101.38 & 129.37 & \\
\hline
\end{tabular}

a (nmol/mg oil) shows the contents (nmol) of nine fatty acids 1 - 9 included in (mg oil) of eight vegetable oils 1 - 8 .

${ }^{\mathrm{b}} \mathrm{g} / 100 \mathrm{~g}$ shows the total contents $(\mathrm{g})$ of nine fatty acids $1-9$ included in $100 \mathrm{~g}$ of eight vegetable oils $1-8$.

${ }^{c}$ Av: Average value of three times measurements. Values of SD are listed in Table S2. 
Table 4 The $\boldsymbol{k}_{\mathrm{Q}}^{\mathrm{LH}}(S)$ and $\boldsymbol{k}_{\mathrm{Q}}^{\mathrm{LH}}\left(t_{1 / 2}\right)$ and $\boldsymbol{k}_{\mathrm{S}}^{\mathrm{LH}}$ values for fatty acid esters (LHs I - V) and $\boldsymbol{\alpha}$-tocopherol in ethanol/ chloroform $/ \mathrm{D}_{2} \mathrm{O}$ solution.

\begin{tabular}{lcccc}
\hline \multirow{2}{*}{ Fatty acid ester $(\mathrm{LH})$} & $k_{\mathrm{Q}}^{\mathrm{LH}}(S)$ & $k_{\mathrm{Q}}^{\mathrm{LH}}\left(t_{1 / 2}\right)$ & $\begin{array}{c}k_{\mathrm{Q}}^{\alpha-\text {-Toc }}(S) \text { from an } \\
\text { intercept at the y-axis }\end{array}$ & $k_{\mathrm{S}}^{\mathrm{LH}}$ \\
\cline { 2 - 5 } & $\mathrm{M}^{-1} \mathrm{~s}^{-1}$ & $\mathrm{M}^{-1} \mathrm{~s}^{-1}$ & $\mathrm{M}^{-1} \mathrm{~s}^{-1}$ & $\mathrm{M}^{-1} \mathrm{~s}^{-1}$ \\
\hline Ethyl stearate I & $(2.66 \pm 0.57) \times 10^{4 \mathrm{a}}$ & $(2.91 \pm 0.78) \times 10^{4 \mathrm{a}}$ & without $\alpha$-Toc & slow \\
Ethyl oleate II & $(4.22 \pm 0.31) \times 10^{4}$ & $(4.17 \pm 0.37) \times 10^{4}$ & $1.15 \times 10^{8}$ & $(6.07 \pm 0.66) \times 10^{-5} \mathrm{a}$ \\
Ethyl linoleate III & $(4.53 \pm 0.90) \times 10^{4}$ & $(4.47 \pm 0.62) \times 10^{4}$ & $1.16 \times 10^{8}$ & $(6.63 \pm 0.25) \times 10^{-4}$ \\
Methyl linolenate IV & $(5.61 \pm 0.25) \times 10^{4}$ & $(4.80 \pm 0.29) \times 10^{4}$ & $1.35 \times 10^{8}$ & $(8.70 \pm 0.23) \times 10^{-4}$ \\
Glyceryl trioleate V & $(1.29 \pm 0.14) \times 10^{5}$ & $(9.56 \pm 0.89) \times 10^{4}$ & without $\alpha-$ Toc & - \\
$\alpha$-Tocopherol & $1.31 \times 10^{8}$ & $1.29 \times 10^{8}$ & & $7.37 \times 10^{3 \mathrm{~b}}$ \\
\hline
\end{tabular}

${ }^{a}$ Values are expressed as mean $\pm \mathrm{SD}$.

${ }^{\mathrm{b}}$ Value is reported in Ref. 29.

the $S_{\text {blank }} / S_{\mathrm{AO}} \mathrm{vs}[\mathrm{AO}]$ plot.

We can easily obtain Eq. (4), by substituting the relation for the first-order reaction $\left(t_{1 / 2}{ }^{\mathrm{AO}}=\ln 2 / S_{\mathrm{AO}}\right)$ into Eq. (3).

$$
t_{1 / 2}^{\mathrm{AO} / t_{1 / 2}} \text { blank }=1+\left\{k_{\mathrm{Q}}^{\mathrm{AO}}\left(t_{1 / 2}\right)[\mathrm{AO}]\right\} / k_{\mathrm{d}}
$$

where $t_{1 / 2}^{\text {blank }}$ and $t_{1 / 2}{ }^{\mathrm{AO}}$ are the half-lives of DPBF in the absence and presence of the $\mathrm{AO}$, respectively. Equation (4) indicates that the $k_{\mathrm{Q}}{ }^{\mathrm{AO}}\left(t_{1 / 2}\right)$ value can be obtained from the $t_{1 / 2}^{\mathrm{AO}} / t_{1 / 2}^{\text {blank }}$ vs $[\mathrm{AO}]$ plot.

\subsection{GC measurement of the concentrations of the nine fatty acids in vegetable oils $1-8$}

The fatty acid compositions of the vegetable oils were analyzed by previously reported GC methods ${ }^{34,35)}$. First, 5 $\mathrm{mg}$ of a vegetable oil was mixed with an internal standard (20 $\mu \mathrm{g}$ of nonadecanoic acid). Then, $2 \mathrm{~mL}$ of methanol containing hydrogen chloride $(5 \%, \mathrm{v} / \mathrm{v})$ and $5 \mu \mathrm{L}$ of methanol containing dibutylhydroxytoluene $(0.01 \%$, wt $/ \mathrm{v})$ were added. After the nitrogen substitution, the sample was methyl esterified $\left(100^{\circ} \mathrm{C}, 1 \mathrm{~h}\right)$. To stop the methyl esterification reaction, $5 \mathrm{~mL}$ of aq. potassium carbonate (6\%, wt/ v) was added. Then, $1 \mathrm{~mL}$ of hexane was added and partitioned by centrifugation $\left(1630 \times \mathrm{g}, 4^{\circ} \mathrm{C}, 10 \mathrm{~min}\right)$ into two layers. The upper hexane layer was collected, and the remaining aqueous layer was re-extracted with $1 \mathrm{~mL}$ of hexane. The combined hexane layer was evaporated under a nitrogen gas, and the residue was dissolved in $200 \mu \mathrm{L}$ of hexane. Samples of 0.7-2 $\mu \mathrm{L}$ were subjected to GC-4000 (GL Sciences Inc., Tokyo, Japan) equipped with a DB-225 column (length, $30 \mathrm{~m}$; internal diameter, $0.32 \mathrm{~mm}$; film thickness, $0.25 \mu \mathrm{m}$; Agilent Technologies, Santa Clara, CA, USA). Helium gas was used as the mobile phase. The injector and detector temperatures were set at 220 and $250^{\circ} \mathrm{C}$ respectively. The gradient profile was as follows: 140 $180^{\circ} \mathrm{C}\left(8^{\circ} \mathrm{C} / \mathrm{min}\right.$ linear $), 180-220^{\circ} \mathrm{C}\left(3^{\circ} \mathrm{C} /\right.$ min linear $)$, and $220^{\circ} \mathrm{C}$ (for $25 \mathrm{~min}$ ). Each concentration was determined in triplicate, and the average values are listeded in Table 3. The values of the standard deviations (SDs) are listed in
Table S2.

\section{Results}

3.1 Contents of the nine fatty acids in vegetable oils $1-8$

Measurements of the concentrations of the fatty acids contained in vegetable oils 1 - 8 were performed using GC, as described in Sec. $2.4^{34,35)}$. The obtained concentrations of fatty acids 1 - 9 are listed in Table $3(\mathrm{nmol} / \mathrm{mg}$ oil unit) (or Table S3 (g/100 g oil unit)). As can be seen from Table 3 , the total concentrations ( $\mathrm{nmol} / \mathrm{mg}$ oil) of fatty acid $1-9$ contained in vegetable oils 1 - 8 increased in the order:

myristic acid $(\mathrm{C} 14: 0)<$ palmitoleic acid $(\mathrm{C} 16: 1)<$ arachidic acid (C20:0)

$<$ vaccenic acid $(\mathrm{C} 18: 1)<$ stearic acid $(\mathrm{C} 18: 0)<$ palmitic $\operatorname{acid}(\mathrm{C} 16: 0)$

$<\alpha$-linolenic acid $(\mathrm{C} 18: 3)<$ linoleic acid $(\mathrm{C} 18: 2)<$ oleic $\operatorname{acid}(\mathrm{C} 18: 1)$

Oleic acid has the highest total concentration among the nine fatty acids. Linoleic acid and $\alpha$-linolenic acid having high degrees of unsaturation also exibit high concentrations. The concentrations of the saturated fatty acids (i.e. myristic, arachidic, stearic, and palmitic acids) are lower than those of the above unsaturated fatty acids.

The total concentrations ( $\mathrm{g} / 100 \mathrm{~g}$ oil) of fatty acids $1-9$ contained in oils $1-8$ are extremely high and vary from $75.707 \mathrm{~g} / 100 \mathrm{~g}$ of rice bran oil 1 to $85.520 \mathrm{~g} / 100 \mathrm{~g}$ of extra virgin olive oil 6, as listed in the rightmost column in Table 3. However, the differences in the total concentrations of fatty acids $1-9$ contained in vegetable oils $1-8$ are not significantly large. Examples of such a detailed analysis of the concentrations of numerous fatty acids contained in vegetable oils are limited to our knowledge ${ }^{12,17,26)}$.

Using the obtained concentrations of the nine fatty acids (i.e. [Acid- $i(\mathrm{~g} / 100 \mathrm{~g}$ oil $)]$ ) (Table S3), the $k_{Q}{ }^{\text {Acid }}$ (calcd.) 
values (Table 1) were calculated, as described subsequently in Sec. 4.1. The contributions of the fatty acids to the $k_{Q}{ }^{\text {oil }}$ (Obsd.) values were ascertained for oils $1-8$.

\section{2 ${ }^{1} \mathrm{O}_{2}$-quenching rate constants $\left(k_{\mathrm{Q}}{ }^{\mathrm{LH}}\right)$ for fatty acid es- ters I - V in ethanol/chloroform $/ \mathrm{D}_{2} \mathrm{O}$ solution}

Measurements of the $k_{\mathrm{Q}}{ }^{\mathrm{LH}}(S)$ and $k_{\mathrm{Q}}{ }^{\mathrm{LH}}\left(t_{1 / 2}\right)$ values were performed for five fatty acid esters (LHs I - V) (Fig. 1) in mixed solvent ${ }^{22-25)}$. Figure $2(\mathrm{~A})$ shows an example of the interaction between $\operatorname{DPBF}\left(6.17 \times 10^{-5} \mathrm{M}\right)$ and $\operatorname{EP}(8.39 \times$ $10^{-4} \mathrm{M}$ ) without an $\mathrm{AO}$ (i.e. $\alpha$-Toc) in mixed solvent at $35.0^{\circ} \mathrm{C}$. Under the reaction, the appearance of the absorption of the EP precursor at $\lambda_{\max }=288 \mathrm{~nm}$ due to the thermal decomposition of $\mathrm{EP}$ (i.e., the production of ${ }^{1} \mathrm{O}_{2}$ ) and the disappearance of DPBF at $413 \mathrm{~nm}$ due to the chemical reaction between DPBF and the ${ }^{1} \mathrm{O}_{2}$ produced are observed simultaneously (Scheme 1) ${ }^{38)}$.

$\mathrm{DPBF}$ is stable in mixed solvent under the coexistence of LHs I and V. However, the UV-vis absorption spectrum of DPBF varies under the coexistence of LH III, indicating the decomposition of DPBF (Fig. 2(B)). The absorption of DPBF at $413 \mathrm{~nm}$ decreases gradually. A similar decay of the absorption of DPBF at $413 \mathrm{~nm}$ was observed under the coexistence of LHs II and IV. Figure 2(C) exhibits the time dependence of the absorption at $\lambda_{\max }(=413 \mathrm{~nm})$ of DPBF under the coexistence of LHs II, III, and IV. The aspect of the change in the absorption of DPBF in the region between $\lambda=350$ and $450 \mathrm{~nm}$ is similar to that due to the reaction between DPBF and ${ }^{1} \mathrm{O}_{2}$, suggesting that oxidation reaction of $\mathrm{DPBF}$ (Scheme 1) occurs under the coexistence of LHs II - IV in mixed solvent. However, the reason why the decomposition of DPBF occurs in the simultaneous

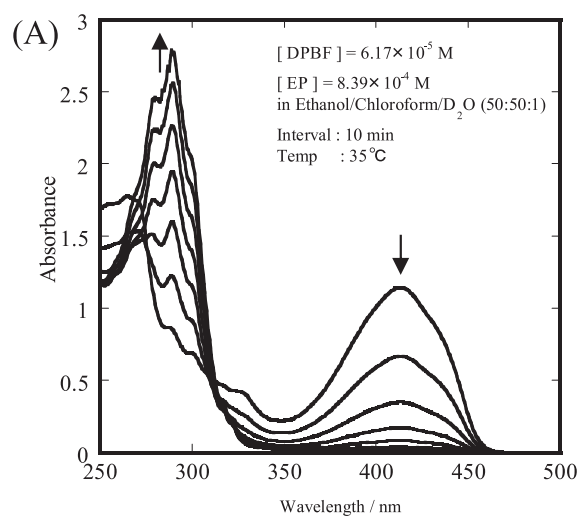

(B)
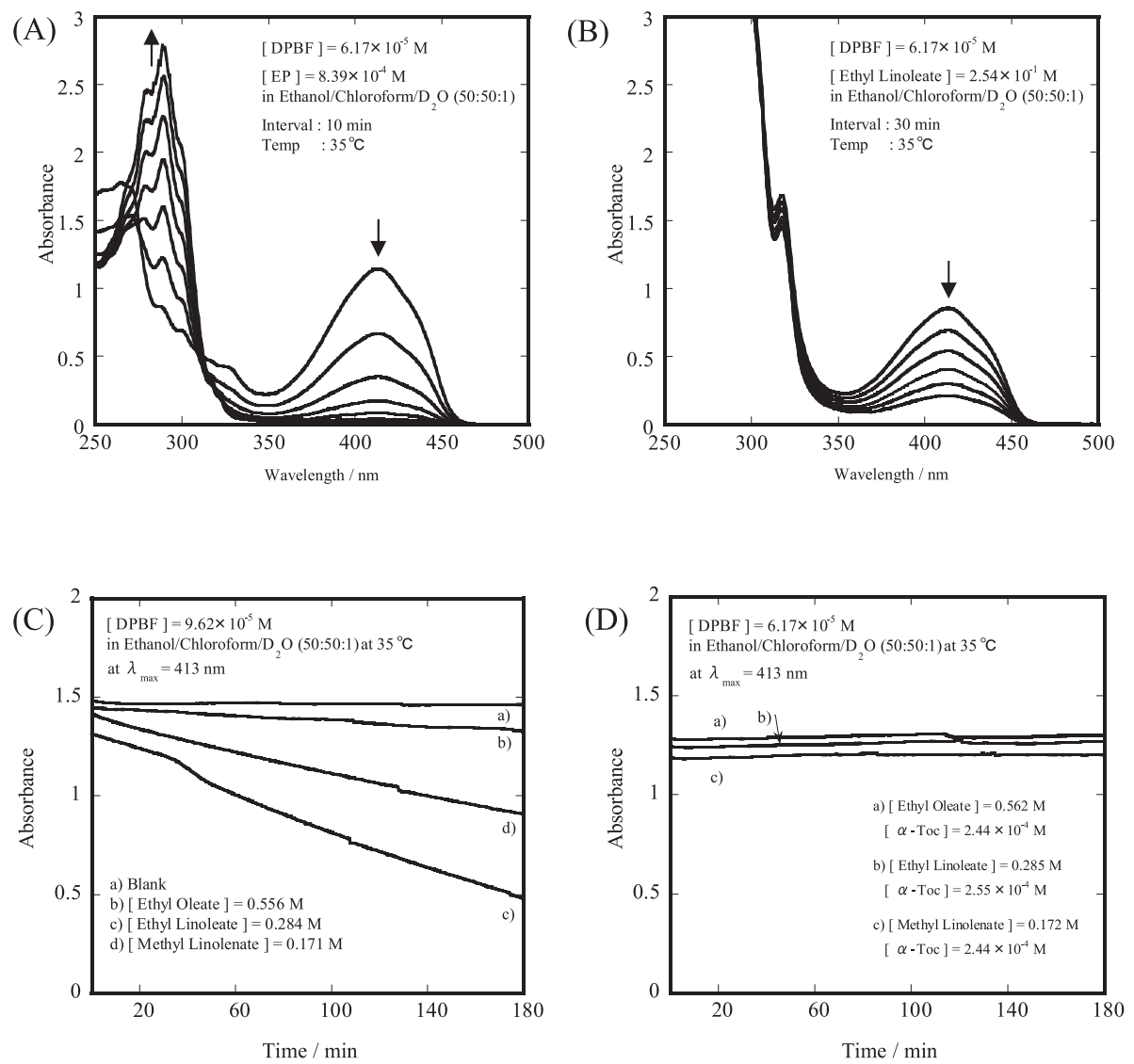

Fig. 2 (A) Change in electronic absorption spectrum of DPBF and endoperoxide(EP) during reaction of DPBF with EP in ethanol/chloroform $/ \mathrm{D}_{2} \mathrm{O}$ solution at $35^{\circ} \mathrm{C}$. $[\mathrm{DPBF}]_{t=0}=6.17 \times 10^{-5} \mathrm{M}$ and $[\mathrm{EP}]_{t=0}=8.39 \times 10^{-4} \mathrm{M}$. The spectra were recorded at 10 min intervals. The arrow indicates a decrease and increase in absorbance of DPBF and EP-precursor with time, respectively. (B) Change in electronic absorption spectrum of DPBF under the coexistence of ethyl linoleate in ethanol/chloroform $/ \mathrm{D}_{2} \mathrm{O}$ at $35^{\circ} \mathrm{C}$. $[\mathrm{DPBF}]_{t=0}=6.17 \times 10^{-5} \mathrm{M}$. [Ethyl linoleate] $=2.54 \times 10^{-1} \mathrm{M}$. The spectra were recorded at 30 min intervals. The arrow indicates a decrease in absorbance of DPBF. (C) Time dependence of absorbance of DPBF at $413 \mathrm{~nm}$ under the coexistence of LHs II, III, and IV in ethanol/chloroform/ $\mathrm{D}_{2} \mathrm{O}$. (D) Time dependence of absorbance of DPBF at $413 \mathrm{~nm}$ under the coexistence of a) LH II and $\alpha$-Toc, b) LH III and $\alpha$-Toc, and c) LH IV and $\alpha$-Toc in ethanol/chloroform $/ \mathrm{D}_{2} \mathrm{O}$. 
presence of LHs II - IV is not clear at present.

However, by adding $\alpha$-Toc to the DPBF solution containing LH II - IV, the decay of the absorption of DPBF disappears, as shown in Fig. 2(D). Therefore, measurements of the $k_{\mathrm{Q}}(S)$ and $k_{\mathrm{Q}}\left(t_{1 / 2}\right)$ values for LH II - IV were performed under the presence of $\alpha$-Toc. For example, measurements of $k_{\mathrm{Q}}{ }^{\mathrm{LH} \text { IV }}(S)$ and $k_{\mathrm{Q}}{ }^{\mathrm{LH} \text { IV }}\left(t_{1 / 2}\right)$ for LH IV were performed by maintaining $\alpha$-Toc at a constant concentration $([\alpha-$ Toc $]=$ $4.14 \times 10^{-4} \mathrm{M}$ ) and by varying the concentration of LH IV ([LH IV] ) (Fig. 3). The disappearance of DPBF was measured at $413 \mathrm{~nm}$, as shown in Fig. 3(A). In such a case, we

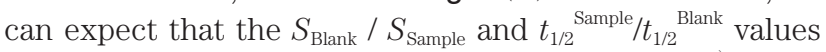
change depending on Eqs. (6) and (7), respectively ${ }^{23)}$.

$$
\begin{aligned}
S_{\text {Blank }} / S_{\text {Sample }}= & 1+\left\{k_{\mathrm{Q}}^{\mathrm{LH}}(S)[\mathrm{LH}]\right\} / k_{\mathrm{d}}+\left\{k_{\mathrm{Q}}{ }^{\alpha-\mathrm{Toc}}(S)\right. \\
& {[\alpha-\mathrm{Toc}]\} / k_{\mathrm{d}} }
\end{aligned}
$$

and

$$
\begin{aligned}
t_{1 / 2}^{\text {Sample }} / t_{1 / 2}^{\text {Blank }}= & 1+\left\{k_{\mathrm{Q}}^{\mathrm{LH}}\left(t_{1 / 2}\right)[\mathrm{LH}]\right\} / k_{\mathrm{d}}+\left\{k_{\mathrm{Q}}{ }^{\alpha-\mathrm{Toc}}\left(t_{1 / 2}\right)\right. \\
& {[\alpha-\mathrm{Toc}]\} / k_{\mathrm{d}} }
\end{aligned}
$$

where $k_{\mathrm{Q}}{ }^{\mathrm{LH}}(S)$ and $k_{\mathrm{Q}}{ }^{\alpha-T o c}(S)$ are the quenching rate constants for LH IV and $\alpha$-Toc, respectively.
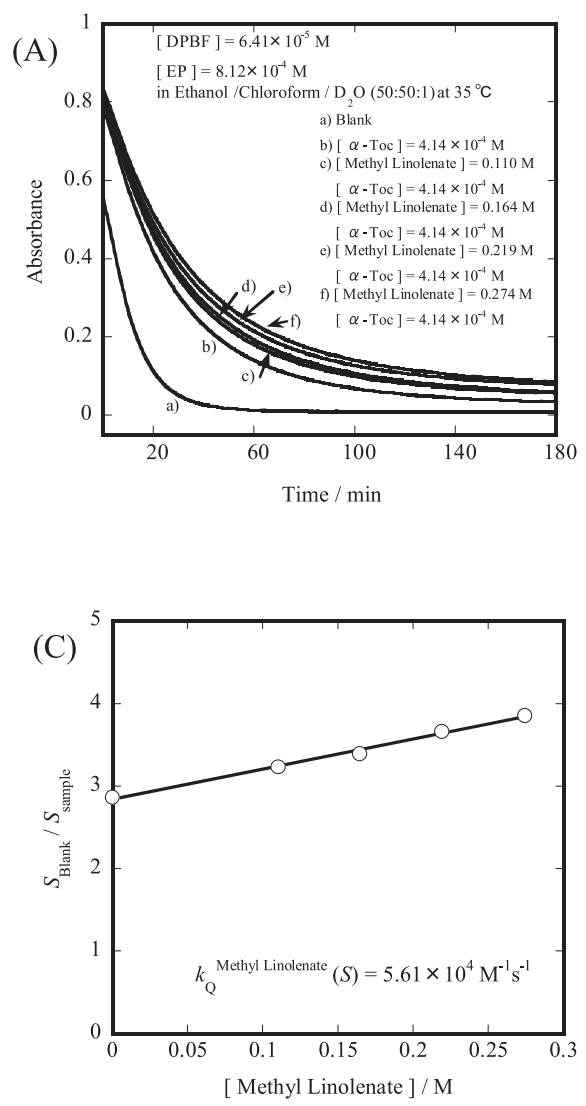

Figure 3(C) displays the $S_{\text {Blank }} / S_{\text {Sample }}$ vs $[\mathrm{LH}$ IV $]$ plot. From the gradient, we obtained the value of $k_{\mathrm{Q}}{ }^{\mathrm{LH} \text { IV }}(S)$ ( = $\left.(5.61 \pm 0.25) \times 10^{4} \mathrm{M}^{-1} \mathrm{~S}^{-1}\right)$, where \pm 0.25 is SD. Further, we can determine the $k_{\mathrm{Q}}{ }^{\alpha \text {-Toc }}(S)$ value from the intercept at the y-axis (i.e., $1+\left\{k_{\mathrm{Q}}^{\alpha-\text { Toc }}(S)[\alpha-\right.$ Toc $\left.\left.]\right\} / k_{\mathrm{d}}\right)$ in Fig. 3(C), using Eq. (6). The $k_{\mathrm{Q}}{ }^{\alpha-T o c}(S)$ value $\left(1.35 \times 10^{8} \mathrm{M}^{-1} \mathrm{~s}^{-1}\right)$ obtained exhibits good accordance with the corresponding value $\left(1.31 \times 10^{8} \mathrm{M}^{-1} \mathrm{~S}^{-1}\right)^{22,23)}$ reported for $\alpha$-Toc, as listed in Table 4. The $k_{\mathrm{Q}}{ }^{\mathrm{LH} I V}\left(t_{1 / 2}\right)$ value is obtained from the $t_{1 / 2}^{\text {Sample }} / t_{1 / 2}^{\text {Blank }}$ vs [LH IV] plot(Fig. 3(D)). Similar measurements were made for LHs II and III in mixed solvent. The obtained $k_{\mathrm{Q}}(S)$ and $k_{\mathrm{Q}}\left(t_{1 / 2}\right)$ values are summarized in Table 4.

However, because DPBF is stable under the simultaneous presence of LH I and V, addition of $\alpha$-Toc is not necessary. Consequently, the rate constants $\left(k_{\mathrm{Q}}(S)\right.$ and $\left.k_{\mathrm{Q}}\left(t_{1 / 2}\right)\right)$ were analyzed using Eqs. (3) and (4), respectively (data are not shown). The $k_{Q}(S)$ values of LHs I - V exhibit good agreement with the corresponding $k_{Q}\left(t_{1 / 2}\right)$ values (Table 4$)$. These results indicate that accurate analyses of the rate $\operatorname{constants}\left(k_{\mathrm{Q}}(S)\right.$ and $\left.k_{\mathrm{Q}}\left(t_{1 / 2}\right)\right)$ are achieved for LHs I - V.
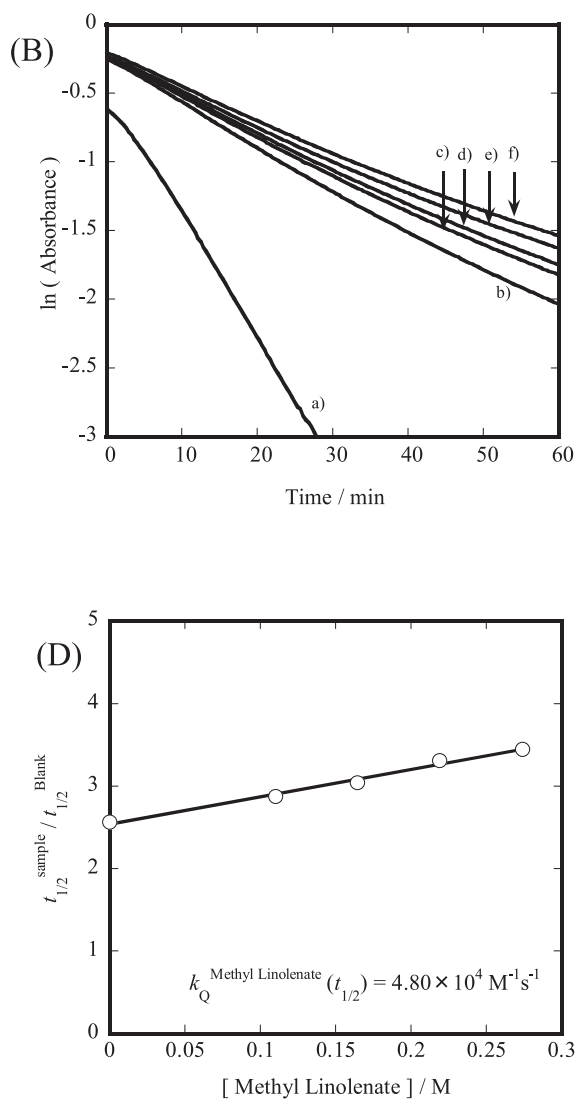

Fig. 3 Measurement of the second-order rate constant $\left(k_{\mathrm{Q}}{ }^{\text {Methyl linolenate IV }}\right)$ for the reaction of methyl linolenate IV with ${ }^{1} \mathrm{O}_{2}$. (A) Change in the absorbance of DPBF at $413 \mathrm{~nm}$ during the reaction of DPBF with ${ }^{1} \mathrm{O}_{2}$ in the absence and presence of AOs ( $\alpha$-tocopherol and methyl linolenate) in ethanol/chloroform $/ \mathrm{D}_{2} \mathrm{O}$ solution at $35^{\circ} \mathrm{C}$. $[\mathrm{DPBF}]=6.41 \times 10^{-5} \mathrm{M}$ and $[\mathrm{EP}]=8.12 \times 10^{-4} \mathrm{M}$. (B) Plot of $\ln ($ Absorbance $)$ vs time. (C) Plot of $S_{\text {Blank }} / S_{\text {Sample }}$ vs [Methyl Linolenate]. (D) Plot of $t_{1 / 2}^{\text {Sample }} / t_{1 / 2}^{\text {Blank }}$ vs [Methyl Linolenate]. 
(A)

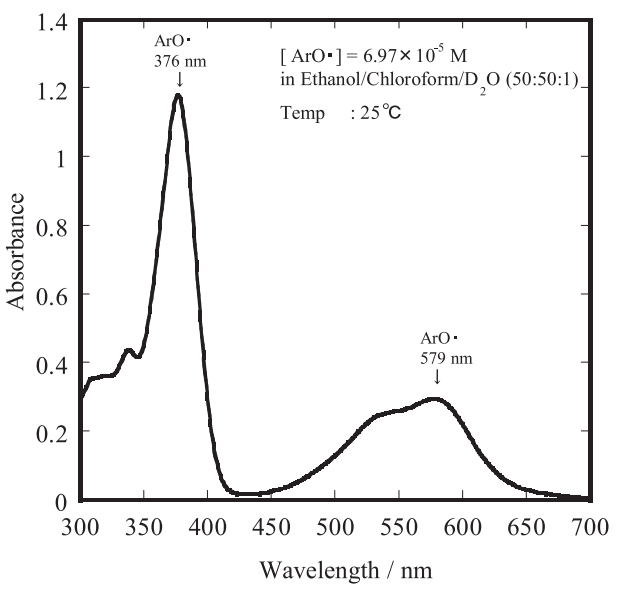

(B)

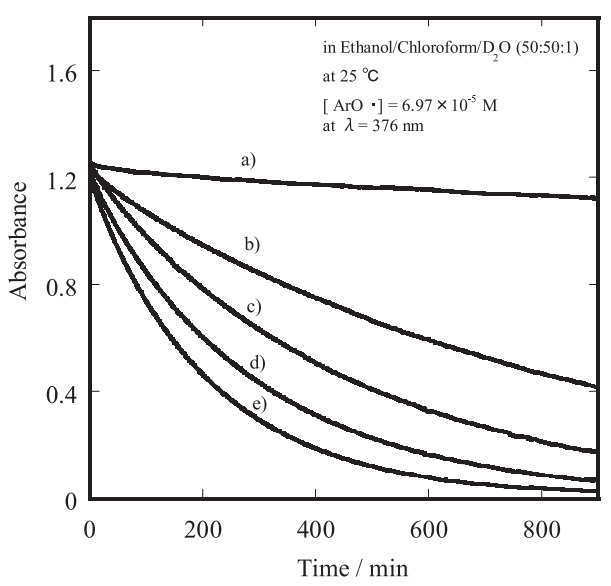

(C)

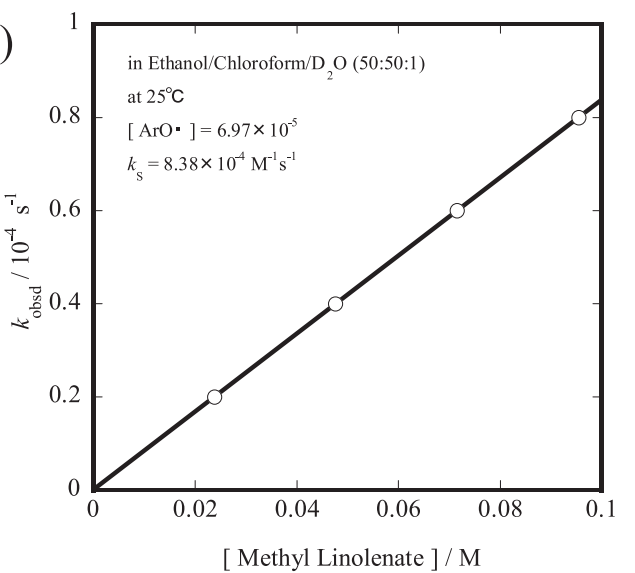

Fig. 4 (A) UV-visible absorption spectrum of aroxyl radical $(\mathrm{ArO} \cdot)$ in ethanol/chloroform/ $/ \mathrm{D}_{2} \mathrm{O}$ solution. (B) Decay of $\mathrm{ArO} \cdot$ radical for the reaction of $\mathrm{ArO} \cdot$ with methyl linolenate IV observed at $376 \mathrm{~nm}$ in ethanol/chloroform $/ \mathrm{D}_{2} \mathrm{O}$ at $25.0^{\circ} \mathrm{C}$. [Methyl Linolenate] =a) $0 \mathrm{M}$, b) $2.39 \times 10^{-2} \mathrm{M}$, c) $4.77 \times 10^{-2}$ $\mathrm{M}$, d) $7.16 \times 10^{-2} \mathrm{M}$, and e) $9.55 \times 10^{-2} \mathrm{M}$ ). (C) Dependence of the pseudo-first-order rate $\operatorname{constant}\left(k_{\text {obsd }}^{\text {LH IV }}\right)$ on the concentration of methyl linolenate IV in ethanol/chloroform/ $\mathrm{D}_{2} \mathrm{O}$.
As listed in Table 4, the $k_{Q}(S)$ values increase in the order of

$$
\text { LH I }<\text { LH II }<\text { LH III }<\text { LH IV }<\text { LH V }
$$

Specifically, the $k_{Q}(S)$ values of LHs I - IV increased following an increase in the numbers of double bond included in a molecule. The $k_{Q}(S)$ value $\left(1.29 \times 10^{5} \mathrm{M}^{-1} \mathrm{~S}^{-1}\right)$ of the $\mathrm{LH} \mathrm{V}$ with the highest activity was 4.84 times larger than that $\left(2.66 \times 10^{4}\right)$ of LH I with the lowest activity. Glyceryl trioleate $(\mathrm{LH} \mathrm{V})$ is a glycerine ester of oleic acid (Fig. 1). The $k_{Q}$ $(S)$ value $\left(1.29 \times 10^{5} \mathrm{M}^{-1} \mathrm{~S}^{-1}\right)$ of $\mathrm{LH} \mathrm{V}$ is 3.06 times larger than that $\left(4.22 \times 10^{2}\right)$ of ethyl oleate (LH II), as expected from the molecular structures of LH II and LH V.

The fatty acids contained in vegetable oils $1-8$ generally exist as fatty acid esters of glycerine. The result of the measurements of the $k_{Q}(S)$ values for ethyl oleate (LH II) and glyceryl trioleate (LH V) suggests that the $k_{Q}(S)$ values for the glycerine fatty acid ester may be explained by the simple sum of the $k_{Q}(S)$ values for three types of the fatty acids. The contributions of the glycerol moiety to the ${ }^{1} \mathrm{O}_{2}-$ quenching rate are negligible, i.e., only the fatty acid moieties in LHs I - V contribute to the ${ }^{1} \mathrm{O}_{2}$-quenching rate. From the results, the $k_{\mathrm{Q}}^{\text {Acid- } i}(S)$ values for the nine types of fatty acids $1-9$ were tentatively estimated. Using these values and the concentrations of fatty acids $1-9$ contained in vegetable oils $1-8$, the contributions of the nine fatty acids $1-9$ to $k_{Q}^{\text {Acid }}(S)$ (Calcd.) value (Table 1) were calculated, as subsequently described in Sec. 4.1.2.

\subsection{ArO - -scavenging rate constants $\left(k_{\mathrm{S}}{ }^{\mathrm{LH}}\right)$ for fatty acid esters I - IV in ethanol/chloroform $/ \mathrm{D}_{2} \mathrm{O}$ solution}

$\mathrm{ArO} \cdot$ is stable in the absence of LHs I - IV and shows absorption peaks at $\lambda_{\max }=376 \mathrm{~nm}$ and $579 \mathrm{~nm}$ in mixed solvent $(\text { Fig. } 4(\mathrm{~A}))^{29)}$. By adding excess solution II - IV to a solution of $\mathrm{ArO} \cdot$, the absorption spectrum of $\mathrm{ArO} \cdot$ gradually disappears. Figure 4(B) presents an example of the result of the interaction between $\mathrm{ArO} \cdot\left(6.97 \times 10^{-5} \mathrm{M}\right)$ and methyl linolenate IV (a) $0 \mathrm{M}$, b) $2.39 \times 10^{-2} \mathrm{M}$, c) $4.77 \times 10^{-2}$ $\mathrm{M}$, d) $7.16 \times 10^{-2} \mathrm{M}$, and e) $9.55 \times 10^{-2} \mathrm{M}$ ) in mixed solvent, showing that the decay rate of $\mathrm{ArO} \cdot$ increases with increasing concentration of LH IV. The pseudo-first-order rate $\operatorname{constant}\left(k_{\text {obsd }}\right)$ was obtained by varying the concentration of LH IV. ArO - exhibits a slow natural decay in mixed solvent. Therefore, the $k_{\text {obsd }}$ value for ArO bleaching is given by Eq. (9) .

$$
-\mathrm{d}[\mathrm{ArO} \cdot] / \mathrm{dt}=k_{\mathrm{obsd}}[\mathrm{ArO} \cdot]=\left\{k_{\mathrm{O}}^{\mathrm{ArO} \cdot}+k_{\mathrm{S}}^{\mathrm{LH}}[\mathrm{LH}]\right\}[\mathrm{ArO} \cdot]
$$

where $k_{0}{ }^{\text {ArO }}$ is the rate constant for natural decay of ArO . in the medium and ${k_{\mathrm{S}}}^{\mathrm{LH}}$ is the second-order rate constant for the reaction of $\mathrm{ArO} \cdot$ with the added fatty acid ester $(\mathrm{LH})$. These parameters are obtained by plotting $k_{\text {obsd }}$ against [LH], as shown in Fig. 4(C). Rate constant $k_{\mathrm{S}}{ }_{\mathrm{Obs}}^{\mathrm{LH}} \mathrm{IV}$ obtained for LH IV is $(8.70 \pm 0.23) \times 10^{-4} \mathrm{M}^{-1} \mathrm{~S}^{-1}$. 
Similar measurements were performed for the reaction of $\mathrm{ArO} \cdot$ with LHs II and III in mixed solvent, and the $k_{\mathrm{S}}$ values obtained for them are $(6.07 \pm 0.66) \times 10^{-5}$ and $(6.63$ $\pm 0.25) \times 10^{-4} \mathrm{M}^{-1} \mathrm{~s}^{-1}$, respectively. However, in the case of ethyl stearate (LH I) containing no double bond, the reaction between $\mathrm{ArO} \cdot$ and $\mathrm{LH}$ I was negligible and slow. The $k_{\mathrm{S}}{ }^{\mathrm{LH}}$ values obtained for LH II - IV are summarized in Table 4 , with the $k_{\mathrm{S}}{ }^{\alpha-T o c}$ value reported for $\alpha$-Toc ${ }^{29)}$. As listed in Table 4 , the rate constants $\left(k_{\mathrm{S}}^{\mathrm{LH}}\right)$ increase as the number of double bonds in LH I - IV increases ${ }^{37)}$.

\section{Discussion}

4.1 Comparison of the observed and calculated ${ }^{1} \mathrm{O}_{2}$ quenching rates $\left(k_{\mathrm{Q}}{ }^{\text {Oil }}\right.$ (Obsd.) and $k_{\mathrm{Q}}($ Calcd. $\left.)\right)$ for vegetable oils $1-8$ in ethanol/chloroform/ $/ \mathrm{D}_{2} \mathrm{O}$ solution

4.1.1 Contribution of eight vitamin E homologues to ${ }^{1} \mathrm{O}_{2}$ quenching rate

As reported in a previous study ${ }^{30)}$, the $k_{\mathrm{Q}}{ }^{\text {Oil }}$ (Obsd.) $\left(\mathrm{L} \mathrm{g}^{-1}\right.$ $\mathrm{s}^{-1}$ ) values (Table 1) for vegetable oils $1-8$ were measured by the $S_{\text {Blank }} / S_{\text {Oil }}$ vs $[$ Oil (g/L) ] plot, using Eq. (10).

$$
\begin{aligned}
& S_{\text {Blank }} / S_{\text {Oil }}=1+\left\{k_{\mathrm{Q}}{ }^{\text {Oil }}(\text { Obsd. })[\text { Oil }]\right\} / k_{\mathrm{d}} \\
& k_{\mathrm{Q}}{ }^{\text {Oil }}(\text { Calcd. }) \\
& =\Sigma k_{\mathrm{Q}}^{\text {Toc- } i(\& \text { Toc- }-i)}[\text { Toc- } i(\& \text { Toc- } 3-i)(\mathrm{mg} / 100 \mathrm{~g} \text { unit })] / 10^{5} \\
& \quad+\Sigma k_{\mathrm{Q}}{ }^{\text {LH }-i}[\mathrm{LH}-i(\mathrm{~g} / 100 \mathrm{~g} \text { unit })] / 10^{2}
\end{aligned}
$$

As shown in Eq. (6), the second-order rate constant for the reaction of ${ }^{1} \mathrm{O}_{2}$ with the AOs was expressed as $k_{\mathrm{Q}}{ }^{\mathrm{AO}}(S)$. However, hereafter, $k_{\mathrm{Q}}{ }^{\mathrm{AO}}(S)$ is abbreviated as $k_{\mathrm{Q}}{ }^{\mathrm{AO}}$ for simplicity.

Measurements of the ${ }^{1} \mathrm{O}_{2}$-quenching rate constants $\left(k_{\mathrm{Q}}{ }^{\text {Toc }-i}\right.$ $(\&$ Toc-3-i) ) of Toc- $i$ (and Toc-3-i) were performed in mixed solvent (see Table S4) ${ }^{24,25)}$. The $k_{\mathrm{Q}}{ }^{\text {Toc-3-i }}$ values of the $\alpha-, \beta-$, $\gamma$-, and $\delta$-Toc-3s were in good agreement with those $\left(k_{\mathrm{Q}}{ }^{\text {Toc }-i}\right)$ of the corresponding $\alpha-, \beta-, \gamma-, \delta$-Tocs. Further, as described in the Introduction, the concentrations (mg/100 g) of the $\alpha-, \beta-, \gamma$-, and $\delta$-Tocs and -Toc-3s contained in vegetable oils 1 - 8 were determined in a previous study (Table $\mathrm{S} 1)^{29)}$. Consequently, the $k_{\mathrm{Q}}^{\text {Toc (\& Toc-3) }}$ (Calcd.) values for vegetable oils 1 - 8 were calculated using Eq. (11), i.e., $\Sigma k_{\mathrm{Q}}^{\text {Toc- } i}$ ${ }^{(\& \text { Toc-3-i) }}[$ Toc- $i$ (and Toc-3-i) (mg/100 g unit) $] / 10^{5}$. The details of the calculation for rice bran oil 1 are presented in Table S4 ${ }^{30)}$. The $k_{\mathrm{Q}}{ }^{\text {Toc }-i(\& \text { Toc-3-i) }}$ (Calcd.) and $k_{\mathrm{Q}}{ }^{\text {Oil }}$ (Obsd.) values for rice bran oil 1 are $2.58 \times 10^{2}$ and $7.69 \times 10^{2} \mathrm{~L} \mathrm{~g}^{-1}$ $\mathrm{S}^{-1}$, respectively. The ratio of the rate constants $\left(k_{\mathrm{Q}}^{\text {Toc- } i(\&)}\right.$ Toc-3-i) (Calcd.) $/ k_{\mathrm{Q}}{ }^{\text {Oil }}$ (Obsd.) ) is 0.336.

Similar calculations were performed for vegetable oils 2 8. The $k_{Q}{ }^{\text {Toc- } i(\& \text { Toc-3-i) }}$ (Calcd.) values obtained for oils 1 - 8 are listed in Table 1. The ratios $\left(k_{\mathrm{Q}}{ }^{\text {Toc }-i(\& \text { Toc-3-i) }}\right.$ (Calcd. $) / k_{\mathrm{Q}}{ }^{\text {Oil }}$ (Obsd.)) for oils 1 - 8 vary remarkably from 0.175 to 0.542 . This result indicates that the total ${ }^{1} \mathrm{O}_{2}$-quenching activities of oils 1 - 8 may not be explained by considering only the contribution of the eight vitamin $\mathrm{E}$ homologs contained in vegetable oils 1 - 8. Comparison of the $k_{Q}{ }^{\text {Oil }}$ (Obsd.) and $k_{\mathrm{Q}}{ }^{\text {Toc }-i(\& \text { Toc- }-3-i)}$ (Calcd.) values for oils $1-8$ is shown as a bar graph in Fig. 5.

4.1.2 Contribution of nine fatty acids to ${ }^{1} \mathrm{O}_{2}$-quenching rate

As described in Sec. 3.1., high concentrations of fatty acids 1 - 9 (i.e., total fatty acids $(75.7-85.5) \mathrm{g} / 100 \mathrm{~g}$ oil) (Table 3 ) are contained in vegetable oils $1-8$. Further, measurements of the $k_{\mathrm{Q}}{ }^{\mathrm{LH}}$ values were performed for fatty acid esters I - V (Table 4), to ascertain whether fatty acids $1-9$ contribute to the ${ }^{1} \mathrm{O}_{2}$-quenching of vegetable oils $1-8$. The $k_{\mathrm{Q}}{ }^{\mathrm{LH}}$ values of LHs I - V increase with an increase in the numbers of double bonds present in the molecule(Eq. (8) ). Contributions of the methyl and ethyl groups and glycerol moiety of LH I - V to the ${ }^{1} \mathrm{O}_{2}$-quenching rate are negligible, i.e., only the fatty acid moieties in I - V molecules contribute to the ${ }^{1} \mathrm{O}_{2}$-quenching rate, as described in Sec. 3.2

A similar result was reported by Krasnovsky et $a l .{ }^{39)}$. Ths $k_{\mathrm{Q}}{ }^{\text {Acid }}$ values observed for fatty acids (i.e., palmitic, stearic, oleic, linoleic, and linolenic acids) in $\mathrm{CCl}_{4}$ increased with an increase in the numbers of double bonds. Palmitic and stearic acids exhibited similar $k_{\mathrm{Q}}$ values. Doleiden et $a l^{40)}$ also reported similar results for the $k_{Q}$ values of the methyl esters of fatty acids in pyridine.

Consequently, the $k_{\mathrm{Q}}{ }^{\text {Acid- } i}$ values $\left(\mathrm{M}^{-1} \mathrm{~S}^{-1}\right.$ unit) of the nine types of fatty acids (Acid- $i(i=1-9))$ used for the calculation of the $k_{\mathrm{Q}}^{\text {Acid }}(S)$ (Calcd.) values of vegetable oils $1-8$ were determined tentatively as follows: (i) the $k_{\mathrm{Q}}^{\mathrm{LH}}$ values of ethyl stearate I, ethyl oleate II, ethyl linoleate III, and methyl linolenate IV are considered to be equal to the $k_{\mathrm{Q}}{ }^{\text {Acid }}$ values of stearic acid $4(\mathrm{C} 18: 0)$, oleic acid $5(\mathrm{C} 18: 1)$, linoleic acid $7(\mathrm{C} 18: 2)$, and $\alpha$-linoleic acid $8(\mathrm{C} 18: 3)$, respectively. (ii) the $k_{\mathrm{Q}}{ }^{\text {Acid }}$ values of the saturated fatty acids (i.e. myristic acid $1(\mathrm{C} 14: 0)$, palmitic acid $2(\mathrm{C} 16: 0)$, and arachidic acid $9(\mathrm{C} 20: 0))$ are the same as that of stearic acid 4 (C18:0). (iii) The $k_{\mathrm{Q}}{ }^{\text {Acid }}$ values of palmitoleic acid 3(C16:1) and vaccenic acid $6(\mathrm{C} 18: 1)$ with one double bond in the molecule are the same as that of oleic acid 5(C18:1) (see Table 3). The $k_{\mathrm{Q}}{ }^{\text {Acid- } i}$ values $\left(\mathrm{M}^{-1} \mathrm{~S}^{-1}\right.$ unit) of fatty acids $1-9$ used for the calculation are listed in Table 5. Further, the $k_{\mathrm{Q}}{ }^{\text {Acid }-i}$ values $\left(\mathrm{L} \mathrm{g}^{-1} \mathrm{~s}^{-1}\right.$ unit) of fatty acids $1-9$ were calculated using the molecular weights $(\mathrm{Mw})$ of fatty acid esters I - IV (or fatty acids).

Comparisons of $k_{\mathrm{Q}}{ }^{\text {Oil }}$ (Obsd.) values observed for the above oils 1 - 8 with the sum of the product $\left\{\sum k_{Q}{ }^{\text {Acid- } i}\right.$ [Acid$i]\}$ of the $k_{\mathrm{Q}}^{\text {Acid- } i}$ values assumed for each fatty acid and the concentration ( $[$ Acid- $i(\mathrm{~g} / 100 \mathrm{~g}$ oil $)]$ ) of nine fatty acids (Acid- $i(i=1-9)$ ) (Table S3) contained in oils 1 - 8 were performed using Eq. (11). An example calculated for rice bran oil 1 is shown in Table 5. The contributions of oleic acid 5(LH II), linoleic acid 7 (LH III), and palmitic acid 2 are larger than those of the other six fatty acids. The ratio 


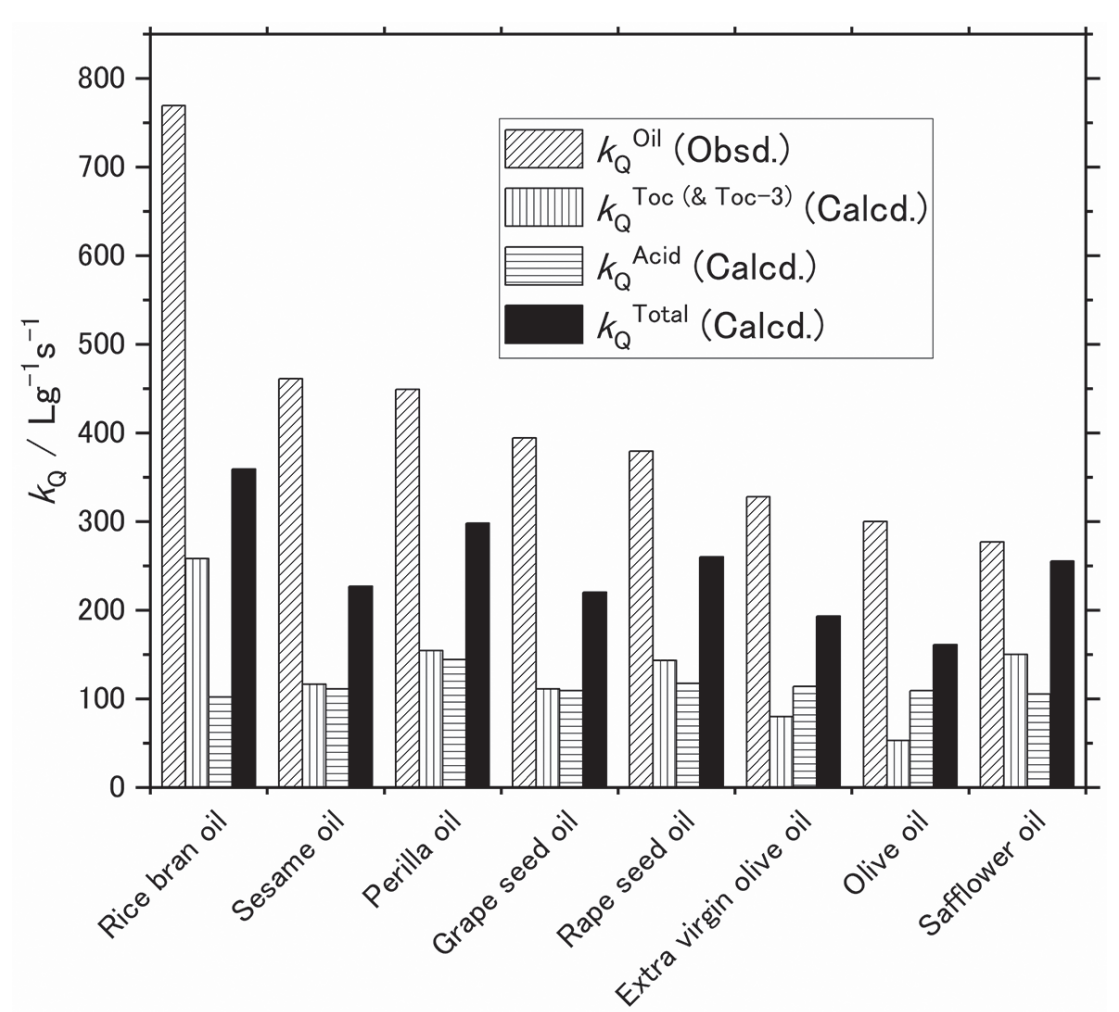

Fig. 5 Comparison of $k_{\mathrm{Q}}{ }^{\text {Oil }}$ (Obsd.), $k_{\mathrm{Q}}{ }^{\text {Toc(\& Toc-3) }}$ (Calcd.), $k_{\mathrm{Q}}{ }^{\text {Acid }}$ (Calcd.), and $k_{\mathrm{Q}}{ }^{\text {Total }}$ (Calcd.) values for eight vegetable oils $1-8$ in ethanol/chloroform/ $\mathrm{D}_{2} \mathrm{O}$ solution.

Table 5 Comparison between observed and calculated ${ }^{1} \mathrm{O}_{2}$-quenching rate constants $\left(k_{\mathrm{Q}}{ }^{\text {Oil } 1}\right.$ (Obsd.) and $\Sigma k_{\mathrm{Q}}{ }^{\text {Acid- } i \text { (or Acid- } i)}$ $\times\left([\right.$ Acid- $\left.i] / 10^{5}\right)($ Calcd. $\left.)\right)$ for rice bran oil 1 in ethanol/chloroform/ $\mathrm{D}_{2} \mathrm{O}$ solution.

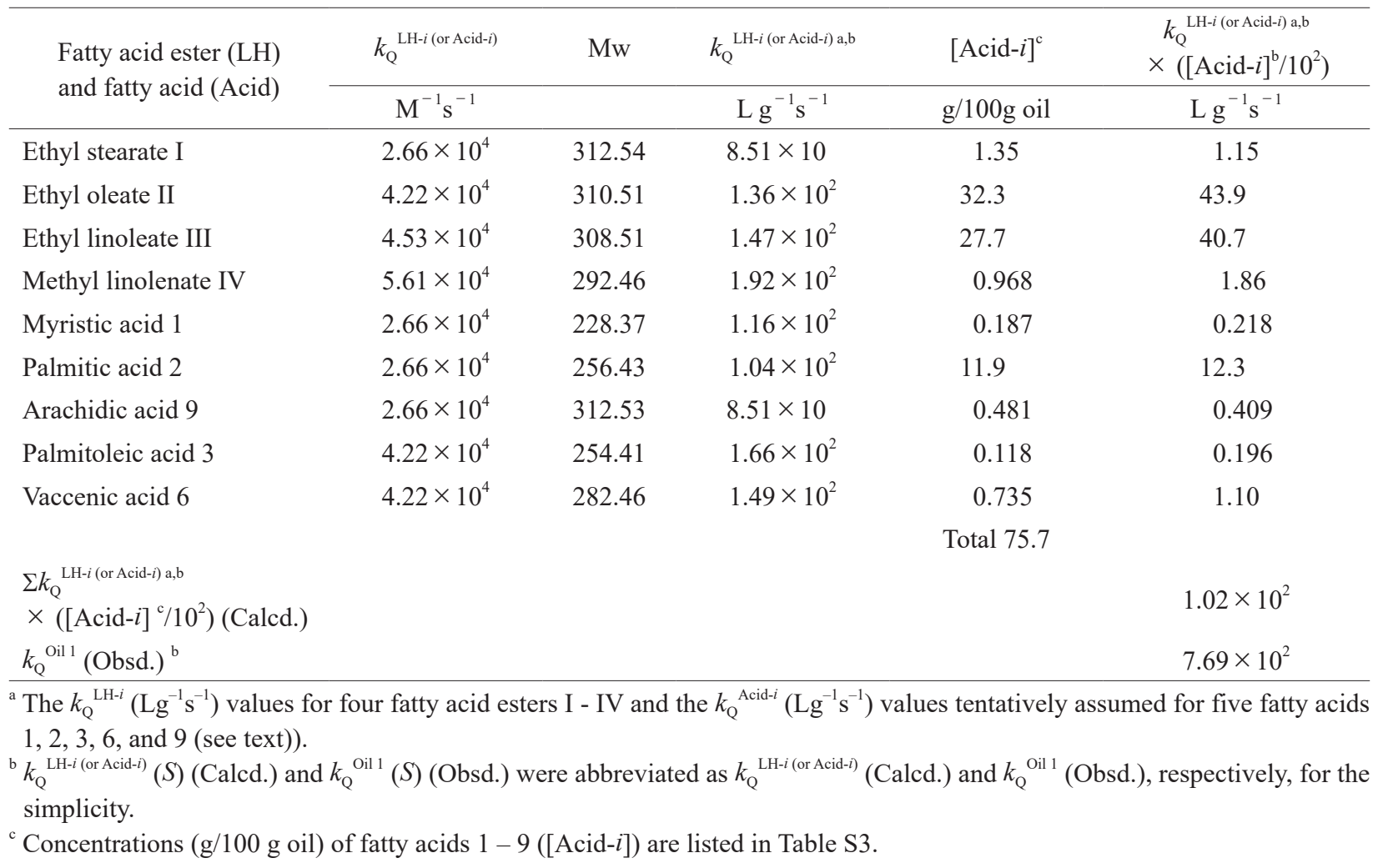


$\left(k_{\mathrm{Q}}{ }^{\text {Acid }}\right.$ (Calcd. $) / k_{\mathrm{Q}}{ }^{\text {Oil }}$ (Obsd. $\left.)\right)$ is 0.133 . The $k_{\mathrm{Q}}^{\text {Acid }}$ (Calcd.) values calculated for vegetable oils $1-8$ are summarized in Table 1. The values of the ratio $\left(k_{\mathrm{Q}}{ }^{\text {Acid }}(\right.$ Calcd. $) / k_{\mathrm{Q}}{ }^{\text {Oil }}$ (Obsd. $\left.)\right)$ are from 0.133 to 0.379 (Table 1 ). The result clearly indicates that fatty acids 1 - 9 present in vegetable oils $1-8$ also contribute to the quenching of ${ }^{1} \mathrm{O}_{2}$.

As listed in Table $1, k_{\mathrm{Q}}{ }^{\text {Toc } \& \text { Toc-3) }}$ (Calcd.) values of rice bran oil 1, rape seed oil 5, and safflower oil 8 are 2.53, 1.22, and 1.43 times larger than the corresponding $k_{Q}^{\text {Acid }}$ (Calcd.) values of oils 1,5 , and 8 , respectively. The result suggests that the contributions of Tocs (and Toc-3s) to ${ }^{1} \mathrm{O}_{2}$-quenching are larger than those of the nine fatty acids. The $k_{\mathrm{Q}}{ }^{\text {Toc }(\&)}$ ${ }^{\text {Toc-3) }}$ (Calcd.) values of sesame oil 2, perrila oil 3, and grape seed oil 4 are almost the same as the corresponding $k_{\mathrm{Q}}{ }^{\text {Acid }}$ (Calcd.) values of oils 2, 3, and 4. However, the $k_{\mathrm{Q}}{ }^{\text {Toc }(\& \text { Toc-3) }}$ (Calcd.) values of extra virgin olive oil 6 and olive oil 7 are 0.699 and 0.483 times smaller than the $k_{\mathrm{Q}}{ }^{\text {Acid }}$ (Calcd.) values of oils 6 and 7 , respectively. The ratios of the contributions of Tocs (and Toc-3s) to those of the fatty acids vary remarkably, depending the concentrations of the Tocs, Toc-3s, and fatty acids present in vegetable oils $1-8$.

As listed in Table 1, the $k_{\mathrm{Q}}{ }^{\text {Toc } \& \text { Toc-3) }}$ (Calcd.) values are calculated for vegetable oils $1-8$. The $k_{\mathrm{Q}}{ }^{\text {Toc }(\& \text { Toc-3) }}$ (Calcd.) values vary from $2.58 \times 10^{2} \mathrm{~L} \mathrm{~g}^{-1} \mathrm{~s}^{-1}$ for rice bran 1 to 5.26 $\times 10 \mathrm{~L} \mathrm{~g}^{-1} \mathrm{~s}^{-1}$ for olive oil 5 . The former is 4.90 times larger than the latter. However, the $k_{Q}{ }^{\text {Acid }}$ (Calcd.) values vary from $1.17 \times 10^{2} \mathrm{~L} \mathrm{~g}^{-1} \mathrm{~S}^{-1}$ for rape seed oil 5 to $1.02 \times 10^{2} \mathrm{~L} \mathrm{~g}^{-1} \mathrm{~S}^{-1}$ for rice bran oil 1, except for perilla oil $3\left(1.44 \times 10^{2} \mathrm{~L} \mathrm{~g}^{-1} \mathrm{~s}^{-1}\right)$. The values are similar to each other. The concentrations of Tocs (and Toc-3s) vary remarkably depending on the types of oils. By contrast, the total concentrations of the fatty acids contained in oils $1-8$ are similar to each other (i.e., from $75.707 \mathrm{~g}(/ 100 \mathrm{~g}$ oil $)$ for rice bran oil 1 to $85.520 \mathrm{~g}(/ 100$ g oil) for extra virgin olive oil 6 ). Consequently, the $k_{\mathrm{Q}}{ }^{\text {Acid }}$ (Calcd.) values calculated for oils $1-8$ are thought to be similar.

Further, the total $k_{\mathrm{Q}}{ }^{\text {Total }}$ (Calcd.) values (i.e., the sum of $k_{\mathrm{Q}}{ }^{\text {Toc(\& Toc-3) }}$ (Calcd.) and $k_{\mathrm{Q}}{ }^{\text {Acid }}$ (Calcd.) ) and the values of the ratio $\left(k_{Q}{ }^{\text {Total }}\right.$ (Calcd.) $/ k_{Q}$ (Obsd. $\left.)\right)$ are listed in Table 1. The ratio varies from 0.467 for rice bran oil 1 to 0.686 for rape seed oil 5, except for 0.921 for safflower oil 8. The values of $k_{\mathrm{Q}}{ }^{\text {Oil }}$ (Obsd.), $k_{\mathrm{Q}}{ }^{\text {Toc }(\& \text { Toc-3) }}$ (Calcd.),$k_{\mathrm{Q}}{ }^{\text {Acid }}$ (Calcd.), and $k_{\mathrm{Q}}{ }^{\text {Total }}$ (Calcd.) obtained for vegetable oils $1-8$ are shown as a bar graph in Fig. 5. The observed $k_{\mathrm{Q}}{ }^{\text {Oil }}$ (Obsd.) values may not be explained by considering the contributions of the four Tocs (and four Toc-3s) and fatty acids $1-9$ contained in vegetable oils $1-7$, except for safflower oil 8. It is necessary to consider the contributions of other AOs contained in vegetable oils $1-8$, to explain the observed $k_{Q}$ (Obsd.) values (i.e., ${ }^{1} \mathrm{O}_{2}$-quenching activity).

As reported in a previous study, measurements of UV-Vis absorption spectra were performed for vegetable oils 1 $8^{30)}$. Perilla oil 3 exhibits a UV-vis absorption at 370 520 $\mathrm{nm}$, suggesting that carotenoids are contained in oil $3^{14,23)}$.
Green colored extra virgin olive oil 6 and olive oil 7 contain chlorophyll a $\left(\lambda_{\max }=414 \mathrm{~nm} \text { and } 668 \mathrm{~nm}\right)^{14)}$ and carotenoids $^{23)}$. As is well-known, the $k_{Q}{ }^{\text {Carotenoid }}$ values of carotenoids are two orders of magnitude larger than those of Tocs (and Toc-3s $)^{16,22)}$. The carotenoids contained in oils 3 , 6 , and 7 will also contribute to the quenching of ${ }^{1} \mathrm{O}_{2}$. However, the degree of the contribution of carotenoids is not clear at present, because the concentrations have not been reported. By contrast, grape seed oil 4, rape seed oil 5 , and safflower oil 8 do not exhibit any absorption in the region above $400 \mathrm{~nm}$, suggesting that carotenoids and chlorophyll a are not present in these oils.

As Eq. (1) indicates, $\alpha$-Toc scavenges ${ }^{1} \mathrm{O}_{2}$ by a combination of physical quenching $\left(k_{\mathrm{q}}\right)$ and chemical reaction $\left(k_{\mathrm{r}}\right)^{41,42)}$. Because $k_{\mathrm{q}} \gg k_{\mathrm{r}}$, the qucnching process is almost entirely "physical", i.e., $\alpha$-Toc deactivates $\sim 120{ }^{1} \mathrm{O}_{2}$ molecules before being destroyed by the chemical reaction ${ }^{41}$. However, the ${ }^{1} \mathrm{O}_{2}$-quenching reactions of the fatty acids differ from that of $\alpha$-Toc (i.e., vitamin $\mathrm{E}$ homologs).

Numerous experimentals were performed for the reaction of ${ }^{1} \mathrm{O}_{2}$ with the fatty acids $(\mathrm{LH})$ (including $\mathrm{C}_{18}-\mathrm{C}_{20}$ carbon atoms) or their esters containing from 1 to 4 double bonds within a molecule. The results obtained by a careful product analysis indicate the production of fatty acid hydroperoxide (LOOH) (Eq. (12) $)^{2-5)}$. Generally, a chemical reaction $\left(k_{\mathrm{r}}\right)$ occurs between unsaturated fatty acids $(\mathrm{LH})$ and ${ }^{1} \mathrm{O}_{2}$, which is different from the $\alpha$-Toc case. The results obtained by a careful product analysis indicate that fatty acid hydroperoxide $(\mathrm{LOOH})$ is generated by the reaction between the $\mathrm{LH}$ and ${ }^{1} \mathrm{O}_{2}$ (Eq. $\left.(12)\right)^{2-5}$.

$$
\begin{gathered}
k_{\mathrm{r}} \\
{ }^{1} \mathrm{O}_{2}+\mathrm{LH} \rightarrow \mathrm{LOOH} \\
k_{\mathrm{q}} \\
{ }^{1} \mathrm{O}_{2}+\mathrm{LH} \rightarrow{ }^{3} \mathrm{O}_{2}+\mathrm{LH}
\end{gathered}
$$

The total $k_{\mathrm{Q}}\left(=k_{\mathrm{q}}+k_{\mathrm{r}}\right)$ values, i.e., the sum of the rate constants for the chemical reaction $\left(k_{\mathrm{r}}\right)$ and physical quenching $\left(k_{\mathrm{q}}\right)$ (Eq. $\left.(13)\right)$ were measured for the fatty acids (or fatty acid esters) by Krasnovsky et $a l^{39}{ }^{39}$ and Doleiden et $a l .{ }^{40)}$. Furthermore, Tanielian and Mechin ${ }^{43)}$ reported both the $k_{\mathrm{q}}$ and $k_{\mathrm{r}}$ values for methyl oleate (MO), methyl linoleate (MLA), and ethyl linolenate (ELN). The $k_{\mathrm{r}}$ and $k_{\mathrm{q}}$ values observed in $\mathrm{CHCl}_{3}$ are as follows: $k_{\mathrm{r}}$ values are $2.43 \times 10^{4}$ $(\mathrm{MO}), 3.77 \times 10^{4}(\mathrm{MLA})$, and $5.28 \times 10^{4} \mathrm{M}^{-1} \mathrm{~s}^{-1}(\mathrm{ELN}) . k_{\mathrm{q}}$ values are $1.24 \times 10^{4}(\mathrm{MO}), 0.95 \times 10^{4}(\mathrm{MLA})$, and $1.06 \times 10^{4}$ $\mathrm{M}^{-1} \mathrm{~s}^{-1}$ (ELN).

As expected, the $k_{\mathrm{r}}$ values are larger than the corresponding $k_{\mathrm{q}}$ values, differing from the result obtained for $\alpha$-Toc. The $k_{\mathrm{r}}$ value increases with increasing number of double bonds (i.e., $\left.k_{\mathrm{r}}(\mathrm{MO})<k_{\mathrm{r}}(\mathrm{MLA})<k_{\mathrm{r}}(\mathrm{ELN})\right)$. However, the $k_{\mathrm{q}}$ values for MO, MLA, and ELN are similar. The total $k_{\mathrm{Q}}$ values $\left(=3.67 \times 10^{4}(\mathrm{MO}), 4.72 \times 10^{4}(\mathrm{MLA})\right.$, and $\left.6.34 \times 10^{4} \mathrm{M}^{-1} \mathrm{~S}^{-1}(\mathrm{ELN})\right)$ in $\mathrm{CHCl}_{3}$ are similar to the 
corresponding $k_{Q}$ (Obsd.) values of LHs II, III, and IV (Table 4) in mixed solvent.

As observed for ethyl stearate I (i.e., the ethyl ester of a saturated fatty acid), the $k_{Q}$ value of ethyl stearate I will be due to physical quenching $\left(k_{\mathrm{q}}\right)$, suggesting that the numerous $\mathrm{CH}_{2}$ and $\mathrm{CH}_{3}$ groups contained in the fatty acids also contribute to ${ }^{1} \mathrm{O}_{2}$-quenching. Further, the results obtained indicate that the numerous biological molecules found in the vegetable oils react with ${ }^{1} \mathrm{O}_{2}$, and contribute to the quenching of ${ }^{1} \mathrm{O}_{2}$. The ${ }^{1} \mathrm{O}_{2}$-quenching activities of vegetables and fruits vary depending on the concentrations of the contained carotenoids ${ }^{14,23)}$. However, the concentrations of the carotenoids contained in vegetable oils $1-8$ are generally low. This is the reason why the $k_{\mathrm{Q}}$ Oil (Obsd.) values observed may not be explained by considering the contributions of the four Tocs (and four Toc-3s) and fatty acids $1-9$ contained in vegetable oils $1-7$, except for safflower oil 8 .

\subsection{Comparison of the observed and calculated ArO -} -scavenging rates $\left(k_{\mathrm{S}}{ }^{\text {Oil }}\right.$ (Obsd.) and $k_{\mathrm{S}}($ Calcd. $\left.)\right)$ for vegetable oils $1-8$ in ethanol/chloroform/ $D_{2} \mathrm{O}$ solution

4.2.1 Contribution of eight vitamin $\mathrm{E}$ homologues to ArO • -scavenging rate

Recently, the rate constants $\left(k_{\mathrm{S}}{ }^{\text {oil }}(\mathrm{Obsd}).\right)$ for the reaction of vegetable oils 1 - 8 with $\mathrm{ArO} \cdot(\mathrm{Eq}$. (2)) were measured in mixed solvent (Table 2 ), to clarify the free radical- scavenging activities of oils $1-8^{29)}$. As reported in a previous study, the $k_{\mathrm{S}}{ }^{\text {Oil }}\left(\mathrm{L} \mathrm{g}^{-1} \mathrm{~S}^{-1}\right)$ values for oils $1-8$ were determined from a plot of $k_{\text {obsd }}$ vs $[\mathrm{Oil}(\mathrm{g} / \mathrm{L})]$ using Eq. (14).

$$
\begin{aligned}
& k_{\text {Obsd }}=k_{\mathrm{o}}+k_{\mathrm{S}}{ }^{\text {Oil }}(\text { Obsd. })[\text { Oil }] \\
& k_{\mathrm{S}}{ }^{\text {Oil }}(\text { Calcd. }) \\
& =\Sigma k_{\mathrm{S}}{ }^{\text {Toc }-i(\& \text { Toc- }-3-i)}[\text { Toc- } i(\& \text { Toc- } 3-i)(\mathrm{mg} / 100 \mathrm{~g} \text { unit })] / 10^{5} \\
& \quad+\Sigma k_{\mathrm{S}}{ }^{\text {Acid- } i}[\text { Acid- } i(\mathrm{~g} / 100 \mathrm{~g} \text { unit })] / 10^{2}
\end{aligned}
$$

Further, the measurements of the $\mathrm{ArO} \cdot$-scavenging rate constants $\left(k_{\mathrm{S}}{ }^{\text {Toc }-i(\& \mathrm{Toc}-3-i)}\right)$ of the $\alpha-, \beta-, \gamma-$, and $\delta$-Tocs (and -Toc-3s) were performed in mixed solvent ${ }^{29)}$. Consequently, the $k_{\mathrm{S}}{ }^{\text {Oil }}$ (Calcd.) values for oils $1-8$ were calculated using Eq. (15), i.e., $\left\{\Sigma k_{\mathrm{S}}{ }^{\text {Toc }-i(\& \text { Toc }-3-i)}[\right.$ Toc- $i$ (and Toc-3-i) $\left.] / 10^{5}\right\}$, where $[$ Toc- $i$ (and Toc-3- $i$ ) ] is the concentration (in $\mathrm{mg} / 100$ g) of the four Tocs (and four Toc-3s) in oils 1 - 8 (Table S1) 29). Details of the calculation for perilla oil 3 are listed in Table S5 ${ }^{29)}$. The $k_{\mathrm{S}}{ }^{\text {Toc }-i(\& \text { Toc-3-i) }}$ (Calcd.) and $k_{\mathrm{S}}{ }^{\text {Oil }}$ (Obsd.) values for perilla oil 3 are $8.66 \times 10^{-3}$ and $9.17 \times 10^{-3} \mathrm{~L} \mathrm{~g}^{-1} \mathrm{~S}^{-1}$, respectively. The ratio of the rate constants $\left(k_{\mathrm{S}}^{\text {Toc- } i(\& \text { Toc-3-i) }}\right.$ (Calcd.) $/ k_{\mathrm{S}}{ }^{\text {Oil }}($ Obsd.) ) is 0.944 (Table 2). Similar results are obtained for the other vegetable oils, except for olive oil 7 , as listed in Table 2 and shown in Fig. 6. The ratio $\left(k_{\mathrm{S}}{ }^{\text {Toc }-i(\&}\right.$ Toc-3-i) $\left(\right.$ Calcd.) $/ k_{\mathrm{S}}{ }^{\text {Oil }}($ Obsd.) $)$ varies from 0.854 for oil 4 to 1.07 for oil 2 . The results indicate that the $k_{\mathrm{S}}^{\text {Oil }}$ (Obsd.) values for oils $1-8$ are well explained by the $k_{\mathrm{S}}^{\text {Toc(\& Toc-3) }}$

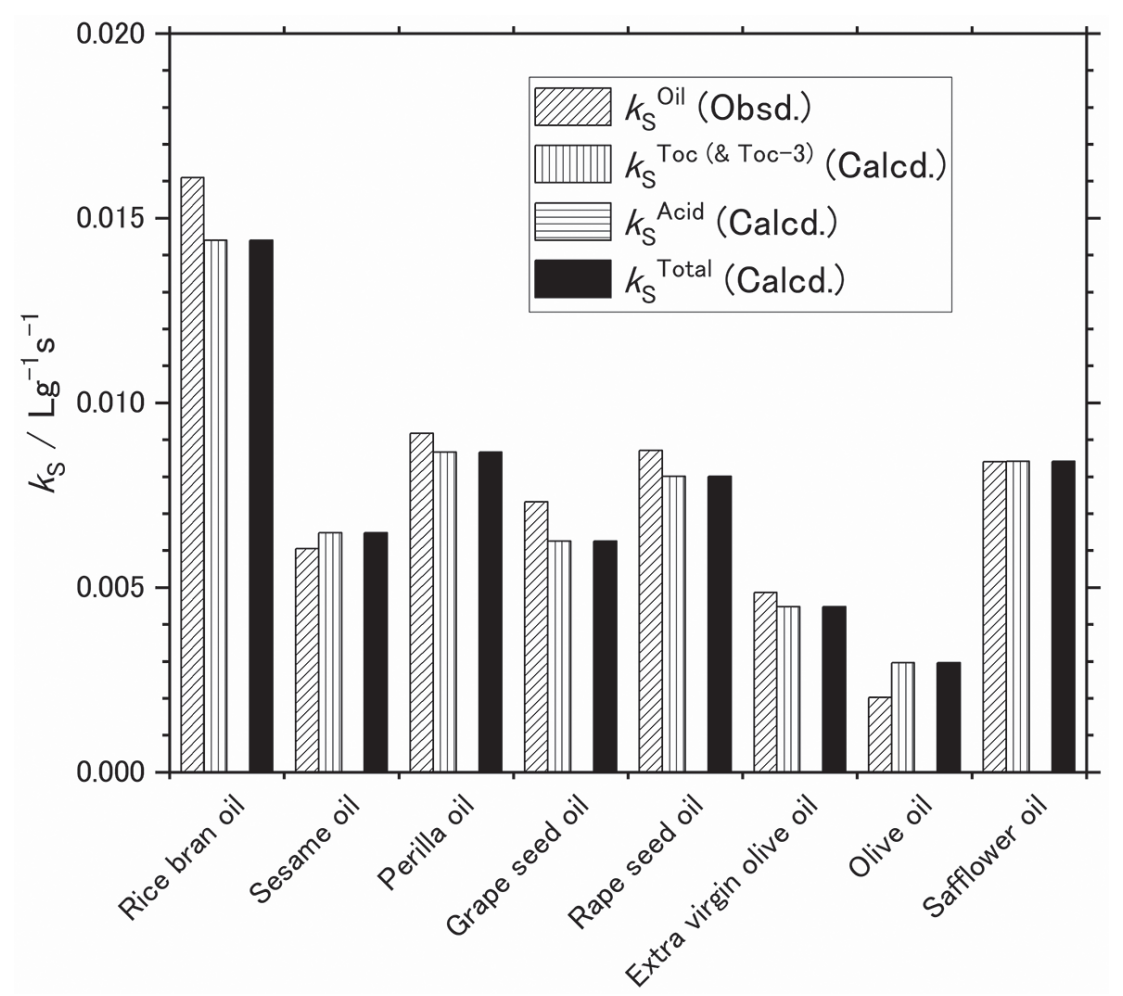

Fig. 6 Comparison of $k_{\mathrm{S}}{ }^{\text {oil }}$ (Obsd.), $k_{\mathrm{S}}{ }^{\text {Toc(\& Toc-3) }}$ (Calcd.), $k_{\mathrm{S}}{ }^{\text {Acid }}$ (Calcd.), and $k_{\mathrm{S}}{ }^{\text {Total }}$ (Calcd.) values for eight vegetable oils $1-8$ in ethanol/chloroform/ $\mathrm{D}_{2} \mathrm{O}$ solution. 
(Calcd.) values calculated using the $k_{\mathrm{S}}{ }^{\mathrm{AO}-i}$ values (AO- $i$ : four Tocs (and four Toc-3s) ) and concentrations of the four Tocs (and four Toc-3s) present in oils $1-8$.

4.2.2 Contribution of the nine fatty acids to the ArO • -scavenging rate

The measurements of $\mathrm{ArO} \cdot$-scavenging rate constants $\left(k_{\mathrm{S}}^{\mathrm{LH}}\right)$ were performed for LH I - IV, as described in Sec. 3.3. The $k_{\mathrm{S}}{ }^{\mathrm{LH}}$ values increased in the order of $\mathrm{LH} \mathrm{I}<\mathrm{II}<\mathrm{III}$ $<\mathrm{IV}$ (Table 4). The $k_{\mathrm{S}}{ }^{\mathrm{LH} \text { I }}$ value for ethyl stearate I is small and negligible. By comparing the $k_{\mathrm{S}}{ }^{\mathrm{LH}}$ values obtained for ethyl oleate II and ethyl linoleate III, the value $\left(6.63 \times 10^{-4}\right.$ $\left.\mathrm{M}^{-1} \mathrm{~S}^{-1}\right)$ of the latter is ca. 11 times larger than that $(6.07 \times$ $\left.10^{-5} \mathrm{M}^{-1} \mathrm{~S}^{-1}\right)$ of the former. Ethyl oleate II has four $-\mathrm{CH}_{2}-$ hydrogen $(\mathrm{H})$-atoms activated by a single $\pi$-electron system $\left(-\mathrm{CH}_{2}^{\mathrm{B}}{ }_{2} \mathrm{C}=\mathrm{C}-\mathrm{CH}_{2^{-}}^{\mathrm{B}}\right)$ (hereafter, we call these $-\mathrm{CH}^{\mathrm{B}}{ }_{2^{-}}$ $\mathrm{H}$-atoms as the B-type of $\mathrm{H}$-atoms). On the other hand, the ethyl linoleate III has two $-\mathrm{CH}_{2}-\mathrm{H}$-atoms activated by two $\pi$-electron systems $\left(-\mathrm{C}=\mathrm{C}-\mathrm{CH}_{2}^{\mathrm{A}}{ }_{2} \mathrm{C}=\mathrm{C}\right.$-) ( similarly, we call these $-\mathrm{CH}^{\mathrm{A}}{ }_{2}$ - $\mathrm{H}$-atoms as the A-type of $\mathrm{H}$-atoms), in addition to the above B-type of four H-atoms. Consequently, these A-type of two H-atoms will mainly contribute to the high reactivity of ethyl linoleate III. LHs III and IV have A-type of two and four H-atoms, respectively, and B-type of four H-atoms. The $k_{\mathrm{S}}{ }^{\mathrm{LH}}$ value $\left(8.70 \times 10^{-4} \mathrm{M}^{-1} \mathrm{~S}^{-1}\right)$ of the latter is ca. 1.3 times larger than that $\left(6.63 \times 10^{-4} \mathrm{M}^{-1} \mathrm{~s}^{-1}\right)$ of the former.

Similar results were obtained for the reactions of fatty acid esters I - IV with the $\alpha$-tocopheroxyl and 5,7-di-iso- propyl-tocopheroxyl radicals, as reported in previous studies $^{44-46)}$. To interpret the results obtained, ab initio molecular orbital calculations of the models for LH I - IV were performed $^{44)}$. The C-H bond dissociation energy $(D)$ decreased and the $\mathrm{C}-\mathrm{H}$ bond length $(r)$ increased in the models of LHs I - III as the number of $\mathrm{C}=\mathrm{C}$ double bonds increased. Further, those were nearly constants in the models of LHs III and IV. From the calculation results, it was shown that the observed features of the rate constant could be explained in terms of the pseudo- $\pi$-conjugation between the $-\mathrm{C}=\mathrm{C}$ - double bond and the active hydrogencarbon bond of $-\mathrm{CH}_{2}$ - group bound with $-\mathrm{C}=\mathrm{C}$ - double bond $\left(-\mathrm{CH}_{2}-\mathrm{C}=\mathrm{C}-\mathrm{CH}_{2}-\right.$ or $\left.-\mathrm{C}=\mathrm{C}-\mathrm{CH}_{2}-\mathrm{C}=\mathrm{C}-\right)$. As described above, the reactions of the $\mathrm{ArO} \cdot$ and $\alpha$-Toc $\cdot$ radicals with LHs II - IV were well explained by the H-atom abstraction reactions between the radicals and LHs II - IV.

Nine types of fatty acids $1-9$ are contained in vegetable oils 1 - 8. As observed for ethyl stearate I, the $k_{\mathrm{S}}^{\text {Acid }}$ values for the saturated fatty acids (i.e., myristic acid 1, palmitic acid 2, and arachidic acid 9) will be extremely small and negligible. Palmitoleic acid 3 and vaccenic acid 6 will show $k_{\mathrm{S}}{ }^{\text {Acid }}$ values similar to that of ethyl oleate II. Linoleic acid 7 and $\alpha$-linolenic acid 8 will exhibit similar $k_{\mathrm{S}}{ }^{\text {Acid }}$ values to those of ethyl linoleate III and methyl linolenate IV, respectively. Therefore, the calculation of the $k_{\mathrm{S}}{ }^{\text {Acid }}$ (Calcd.) values were performed using the $k_{\mathrm{S}}^{\text {Acid- } i}$ values listed in Table 6 .

High concentrations of the fatty acids (i.e., from 75.707 $\mathrm{g} / 100 \mathrm{~g}$ for oil 1 to $85.520 \mathrm{~g} / 100 \mathrm{~g}$ for oil 6 ) are contained in

Table 6 Comparison between observed and calculated ArO $\cdot$-scavenging rate constants $\left(k_{\mathrm{S}}^{\text {Oil } 3}(\right.$ Obsd. $\left.)\right)$ and $\Sigma k_{\mathrm{S}}{ }^{\mathrm{LH}-i}$ (or Acid-i) $\times\left([\right.$ Acid- $\left.i] / 10^{2}\right)$ (Calcd.) for perilla oil 3 in ethanol/chloroform $/ \mathrm{D}_{2} \mathrm{O}$ solution.

\begin{tabular}{|c|c|c|c|c|c|}
\hline $\begin{array}{c}\text { Fatty acid ester (LH) } \\
\text { or fatty acid (Acid) }\end{array}$ & $k_{\mathrm{S}}^{\mathrm{LH}-i \text { (or Acid-i) }}$ & Mw & $k_{\mathrm{S}}^{\mathrm{LH}-i(\text { or Acid-i) a }}$ & {$[\text { Acid- } i]^{\mathrm{b}}$} & $\begin{aligned} & k_{\mathrm{S}}{ }^{\mathrm{LH}-i(\text { or Acid }-i) \mathrm{a}} \\
\times & \left([\text { Acid }-i]^{\mathrm{b}} / 10^{2}\right)\end{aligned}$ \\
\hline & $\mathrm{M}^{-1} \mathrm{~s}^{-1}$ & & $\mathrm{Lg}^{-1} \mathrm{~s}^{-1}$ & $\mathrm{~g} / 100 \mathrm{~g}$ oil & $\mathrm{Lg}^{-1} \mathrm{~s}^{-1}$ \\
\hline Ethyl stearate I & slow $^{c}$ & 312.54 & slow $^{c}$ & 1.22 & - \\
\hline Ethyl oleate II & $6.07 \times 10^{-5}$ & 310.51 & $1.95 \times 10^{-7}$ & 8.34 & $1.63 \times 10^{-8}$ \\
\hline Ethyl linoleate III & $6.63 \times 10^{-4}$ & 308.51 & $2.15 \times 10^{-6}$ & 12.0 & $2.58 \times 10^{-7}$ \\
\hline Methyl linolenate IV & $8.70 \times 10^{-4}$ & 292.46 & $2.97 \times 10^{-6}$ & 56.3 & $1.67 \times 10^{-6}$ \\
\hline Myristic acid 1 & slow & 228.37 & slow & 0.0391 & - \\
\hline Palmitic acid 2 & slow & 256.43 & slow & 4.46 & - \\
\hline Arachidic acid 9 & slow & 312.53 & slow & 0.00 & - \\
\hline Palmitoleic acid 3 & $6.07 \times 10^{-5}$ & 254.41 & $2.39 \times 10^{-7}$ & 0.0752 & $1.80 \times 10^{-10}$ \\
\hline Vaccenic acid 6 & $6.07 \times 10^{-5}$ & 282.46 & $2.15 \times 10^{-7}$ & 0.769 & $1.65 \times 10^{-9}$ \\
\hline $\begin{array}{l}\sum k_{\mathrm{S}}^{\mathrm{LH}-i(\text { or Acid }-i) \mathrm{a}} \\
\times\left([\text { Acid- } i]^{\mathrm{b}} / 10^{2}\right)(\text { Calcd. })\end{array}$ & & & & & $1.95 \times 10^{-6}$ \\
\hline$k_{\mathrm{S}}^{\text {Oil 3 }}$ (Obsd.) & & & & & $9.17 \times 10^{-3}$ \\
\hline
\end{tabular}

${ }^{\text {a }}$ The $k_{\mathrm{S}}^{\mathrm{LH}-i}\left(\mathrm{Lg}^{-1} \mathrm{~S}^{-1}\right)$ values for four fatty acid esters I - IV and the $k_{\mathrm{S}}{ }^{\text {Acid- } i}\left(\mathrm{Lg}^{-1} \mathrm{~S}^{-1}\right)$ values tentatively assumed for five fatty acids $1,2,3,6$, and 9 (see text)).

${ }^{\mathrm{b}}$ Concentrations (g/100 g oil) of fatty acids $1-9$ ([Acid- $\left.\left.i\right]\right)$ are listed in Table S3.

c "slow" means that $k_{\mathrm{S}}^{\mathrm{LH}-i \text { (or Acid-i) }}$ value is below measurelable limits. 
vegetable oils $1-8$ (Table 3 ). Consequently, to ascertain whether the contributions of the fatty acids to the $k_{\mathrm{S}}{ }^{\text {oil }}$ (Obsd.) value are almost negligible or not, the $k_{\mathrm{S}}^{\text {Acid }}$ (Calcd.) values were calculated for vegetable oils $1-8$, using Eq. (15) (i.e., $\Sigma k_{\mathrm{S}}{ }^{\text {Acid- } i}[$ Acid- $i(\mathrm{~g} / 100 \mathrm{~g}$ unit $\left.)] / 10^{2}\right)$. As listed in Table 6, the $k_{\mathrm{S}}{ }^{\text {Acid }}$ (Calcd.) value $\left(1.95 \times 10^{-6} \mathrm{Lg}^{-1} \mathrm{~s}^{-1}\right)$ calculated for perilla oil 3 is ca. three orders of magnitude smaller than $k_{\mathrm{S}}^{\text {Oil } 3}$ (Obsd.) value $\left(9.17 \times 10^{-3} \mathrm{Lg}^{-1} \mathrm{~S}^{-1}\right) \mathrm{ob}-$ served. Similar results are obtained for other vegetable oils 1,2 , and 4 - 8. As listed in Table 2, the $k_{\mathrm{S}}{ }^{\text {Acid }}$ (Calcd.) values for oils $1-8$ are four to five orders of magnitude smaller than the $k_{\mathrm{S}}{ }_{\mathrm{S}}^{\text {oil }}($ Obsd.) values for oils $1-8$. The results indicate that the total $\mathrm{ArO} \cdot$-scavenging activities of the vegetable oils may be explained by only considering the contribution of the $\alpha-, \beta-, \gamma-$, and $\delta$-Tocs and -Toc-3s. It is ascertained that the contributions of the fatty acids to the $\mathrm{ArO} \cdot$-scavenging reaction is extremely small and negligible, differing from the case of the ${ }^{1} \mathrm{O}_{2}$-quenching reaction.

As reported in a previous study, measurements of the UV-Vis absorption spectra were performed for vegetable oils $1-8^{30)}$. The result indicates that numerous types of phenolic AOs (such as $\gamma$-oryzanol, polyphenol, sesamol, and sesamine) are contained in oils $1-8$. These AOs may also contribute to the scavenging of $\mathrm{ArO} \cdot$. However, unexpectedly, the contributions of these AOs are small or almost negligible.

\section{Conclusions}

Recently, measurements of the singlet-oxygen $\left({ }^{1} \mathrm{O}_{2}\right)$ quenching and aroxyl-radical $(\mathrm{ArO} \cdot)$ scavenging rate con$\operatorname{stants}\left(k_{\mathrm{Q}}\right.$ and $k_{\mathrm{S}}$, respectively) of eight vegetable oils 1 - 8 were performed in ethanol/chloroform $/ \mathrm{D}_{2} \mathrm{O}$ solution ${ }^{29,30)}$. Further, the $k_{\mathrm{Q}}$ and $k_{\mathrm{S}}$ values and concentrations of four tocopherols and four tocotrienols contained in the vegetable oils were measured.

In the present study, concentrations of nine fatty acids contained in the above eight vegetable oils (Table 3 ) were determined using gas chromatography. The $k_{\mathrm{Q}}$ and $k_{\mathrm{S}}$ values were measured for ethyl stearate, ethyl oleate, ethyl linoleate, methyl linolenate, and glyceryl trioleate in ethanol/chloroform $/ \mathrm{D}_{2} \mathrm{O}$ solution, using UV-vis spectrophotometry. Based on the results obtained for the above fatty acid esters, the $k_{\mathrm{Q}}$ and $k_{\mathrm{S}}$ values were estimated for the nine fatty acids. Furthermore, comparisons of $k_{Q}$ values observed for the vegetable oils with the sum of the product $\left\{\sum k_{Q}{ }^{\mathrm{AO}-i}[\mathrm{AO}-i]\right\}$ of the $k_{Q}^{\mathrm{AO}-i}$ values obtained for each antioxidant $-i(\mathrm{AO}-i)$ and the concentrations $([\mathrm{AO}-i])$ of $\mathrm{AO}-i$ (i.e., four tocopherols (and four tocotrienols) and the nine fatty acids) contained in vegetable oils were performed. From the results, detailed comparison of the contributions of tocopherols (and tocotrienols) and fatty acids to the ${ }^{1} \mathrm{O}_{2}$ quenching rates $\left(k_{Q}\right)$ was performed, indicating that both the tocopherols (and tocotrienols) and fatty acids contained contribute to the ${ }^{1} \mathrm{O}_{2}$-quenching. A similar comparison was performed for ArO - -scavenging rates $\left(k_{\mathrm{S}}\right)$. The results suggested that only the tocopherols (and tocotrienols) contained contribute to the $\mathrm{ArO} \cdot{ }^{-}$-scavenging and the contributions of fatty acids were negligible.

This is a first example of a kinetic study, where detailed analyses of the contributions of the vitamin E homologs and fatty acids contained in vegetable oils to the ${ }^{1} \mathrm{O}_{2}$ quenching and free radical-scavenging reactions were performed.

\section{Acknowledgments}

This work was partly supported by JSPS KAKENHI Grant Number 18K05518 and the Japan Food Chemical Research Foundation.

\section{Conflict on Interest}

The authors declare no conflicts on interest.

\section{Supporting Information}

This material is available free of charge via the Internet at http://dx.doi.org/jos.69.10.5650/jos.ess 19217

\section{References}

1) Niki, E. Assessment of antioxidant capacity in vitro and in vivo. Free Radical Biol. Med. 49, 503-515 (2010), and references cited therein.

2) Terao, J.; Matsushita, S. Products formed by photosensitized oxidation of unsaturated fatty acid esters. $J$. Am. Oil Chem. Soc. 54, 234-238 (1977).

3) Terao, J.; Matsushita, S. Analysis of photosensitized oxidation products of unsaturated triglycerides and vegetable oils by gas chromatography mass spectrometry. Agric. Biol. Chem. 45, 601-608(1981).

4) Frankel, E.N. Chemistry of free radical and singlet oxidation of lipids. Prog. Lipid Res. 23, 197-221 (1985), and references are cited therein.

5) Girotti, A.W. Photodynamic lipid peroxidation in biological systems. Photochem. Photobiol. 51, 497-509 (1990).

6) Davies, M.J.; Truscott, R.J.W. Photo-oxidation of proteins and its role in cataractogenesis. J. Photochem. Photobiol. B: Biol. 63, 114-125(2001), and references cited therein.

7) Devasagayam, T.P.A.; Steenken, S.; Obendorf, M.S.W.; 
Schulz, W.A.; Sies, H. Formation of 8-(hydroxy (deoxy) guanosine and generation of strand breaks at guanine residues in DNA by singlet oxygen. Biochemisrey 30, 6283-6289 (1991).

8) Piette, J. New trends in photobiology: Biological consequences associated with DNA oxidation mediated by singlet oxygen. J. Photochem. Photobiol. B 11, 241260 (1991).

9) Mangels, A.R.; Holden, J.M.; Beecher, G.R.; Forman, M.R.; Lanza, E. Carotenoid content of fruits and vegetables: an evaluation of analytic data. J. Am. Dietetic Assoc. 93, 284-296 (1993).

10) Holden, J.M.; Eldridge, A.L.; Beecher, G.R.; Buzzard, I.M.; Bhagwat, S.; Davis, C.S.; Douglass, L.W.; Gebhardt, S.; Haytowitz, D.; Schakel, S. Carotenoids content of U. S. foods: An update of database. J. Food Comp. Anal. 12, 169-196(1999), and references cited therein.

11) Sookwong, P.; Nakagawa, K.; Murata, K.; Kojima, Y.; Miyazawa, T. Quantitation of tocotrienol and tocopherol in various rice brans. J. Agric. Food Chem. 55, 461466 (2007).

12) Tuberoso, C.I.G.; Kowalczyk, A.; Sarritzu, E.; Cabras, P. Determination of antioxidant compounds and antioxidant activity in commercial oilseeds for food use. Food Chem. 103, 1494-1501 (2007), and references are cited therein.

13) Hu, J-N.; Zhu, X-M.; Adhikari, P.; Li, D.; Kim, I-H.; Lee, $\mathrm{K}-\mathrm{T}$. Determination of tocopherol contents in refined edible oils using an HPLC method. J. Food Sci. Nutr. 14, 260-264(2009).

14) Iwasaki, Y.; Takahashi, S.; Aizawa, K.; Mukai, K. Development of singlet oxygen absorption capacity (SOAC) assay method. 4. Measurements of the SOAC values for vegetable and fruit extracts. Biosci. Biotechnol. Biochem. 79, 280-291 (2015), and references cited therein.

15) Burton, G.W.; Doba, T.; Gabe, E.J.; Hughes, L.; Lee, F.L.; Prasad, L.; Ingold, K.U. Autoxidation of biological molecules. 4. Maximizing the antioxidant activity of phenols. J. Am. Chem. Soc. 107, 7053-7065(1985).

16) Sies, H.; Stahl, W.; Sundquist, A.R. Antioxidant functions of vitamins. Vitamin $\mathrm{E}$ and $\mathrm{C}, \beta$-carotene, and other carotenoids. Ann. N. Y. Acad. Sci. 669, 7-20 (1992), and references are cited therein.

17) Cabrini, L.; Barzanti, V.; Cipollone, M.; Fiorentini, D.; Grossi, G.; Tolomelli, B.; Zambonin, L.; Landi, L. Antioxidants and total peroxyl radical-trapping ability of olive and seed oils. J. Agric. Food Chem. 49, 60266031 (2001).

18) Krinsky, N.I.; Yeum, K.-J. Carotenoid-radical interactions. Biochem. Biophys. Res. Commun. 305, 754760 (2003), and references are cited therein.

19) El-Agamy, A.; Lowe, G.M.; McGarvey, D.J.; Mortensen,
A.; Phillip, D.M.; Truscott, T.G.; Young, A.J. Carotenoid radical chemistry and antioxidant/pro-oxidant properties. Arch. Biochem. Biophys. 430, 37-48(2004), and references are cited therein.

20) Edge, R.; Truscott, T.G. Singlet oxygen and free radical reactions of retinols and carotenoids --- A review. Antioxidants 7(1), 5(2018); doi:10.3390/antiox7010005.

21) Takahashi, S.; Tsutsumi, A.; Aizawa, K.; Suganuma, H. Daily radical scavenging and singlet oxygen quenching capacity intake from fruits and vegetables in Japan. Food Sci. Technol. Res. 24, 921-933(2018).

22) Ouchi, A.; Aizawa, K.; Iwasaki, Y.; Inakuma, T.; Terao, J.; Nagaoka, S.; Mukai, K. Kinetic study of the quenching reaction of singlet oxygen by carotenoids and food extracts in solution. Development of a singlet oxygen absorption capacity (SOAC) assay method. J. Agric. Food Chem. 58, 9967-9978(2010).

23) Aizawa, K.; Iwasaki, Y.; Ouchi, A.; Inakuma, T.; Nagaoka, S.; Terao, J.; Mukai, K. Development of singlet oxygen absorption capacity (SOAC) assay method. 2. Measurements of the SOAC values for carotenoids and food extracts. J. Agric. Food Chem. 59, 3717-3729 (2011).

24) Mukai, K.; Ouchi, A.; Takahashi, S.; Aizawa, K.; Inakuma, T.; Terao, J.; Nagaoka S. Development of singlet oxygen absorption capacity (SOAC) assay method. 3. Measurements of the SOAC values for phenolic antioxidants. J. Agric. Food Chem. 60, 7905-7916 (2012).

25) Mukai, K.; Ishikawa, E.; Ouchi, A.; Nagaoka, S.; Suzuki, T.; Izumisawa, K.; Koike, T. Kinetic study of the quenching reaction of singlet oxygen by $\alpha-, \beta-, \gamma-$, $\delta$-tocotrienols and palm oil and soybean extracts in solution. Biosci. Biotechnol. Biochem. 78, 2089-2101 (2014).

26) Moreda, W.; Pérez-Camino, M.C.; Cert, A. Gas and liquid chromatograrphy of hydrocarbons in edible vegetable oils. J. Chromatogr. A 936, 159-171 (2001).

27) Syväoja, E.-L.; Piironen, V.; Varo, P.; Kolvistoinen, P.; Salminen, K. Tocopherols and tocotrienols in finnish foods: Oils and fats. J. Am. Oil Chem. Soc. 63, 328329 (1986).

28) Cert, A.; Modera, W.; Pérez-Camino, M.C. Chromatographic analysis of minor constituents in vegetable oils. J. Chromatogr. A 881, 131-148(2000).

29) Mukai, K.; Bandoh, Y.; Ito, J.; Kobayashi, E.; Nakagawa, K.; Nagaoka, S. Kinetic study of the scavenging reaction of the aroxyl radical by eight kinds of vegetable oils in solution. J. Am. Oil Chem. Soc. 95, 731-742 (2018).

30) Mukai, K.; Ohara, A.; Ito, J.; Hirata, M.; Kobayashi, E.; Nakagawa, K.; Nagaoka, S. Kinetic study of the quenching reaction of singlet oxygen by eight vegetable oils in solution. J. Oleo Sci. 68, 21-31 (2019). 
31) Mukai, K.; Fukuda, K.; Tajima, K.; Ishizu, K. A kinetic study of reactions of tocopherols with a substituted phenoxyl radical. J. Org. Chem. 53, 430-432(1988).

32) Mukai, K.; Daifuku, K.; Okabe, K.; Tanigaki, T.; Inoue, K. Structure-activity relationship in the quenching reaction of singlet oxygen by tocopherol (vitamin E) derivatives and related phenols. Finding of linear correlation between the rates of quenching of singlet oxygen and scavenging of peroxyl and phenoxyl radicals in solution. J. Org. Chem. 56, 4188-4192 (1991), and references cited therein.

33) Nagaoka, S.; Nagai, K.; Fujii, Y.; Ouchi, A.; Mukai, K. Development of a new free radical absorption capacity assay method for antioxidants: Aroxyl radical absorption capacity (ARAC). J. Agric. Food Chem. 61, 10054-10062 (2013).

34) Ito, J.; Shimizu, N.; Kobayashi, E.; Hanzawa, Y.; Otoki, Y.; Kato, S.; Hirokawa, T.; Kuwahara, S.; Miyazawa, T.; Nakagawa, K., A novel chiral stationary phase LC-MS/ MS method to evaluate oxidation mechanisms of edible oils. Sci. Rep. 7, 10026 (2017).

35) Kato, S.; Shimizu, N.; Hanzawa, Y.; Otoki, Y.; Ito, J.; Kimura, F.; Takekoshi, S.; Sakaino, M.; Sano, T.; Eitsuka, T.; Miyazawa, T.; Nakagawa, K., Determination of triacylglycerol oxidation mechanisms in canola oil using liquid chromatography-tandem mass spectrometry. NPJ Sci. Food 2, 1 (2018).

36) Rieker, A.; Scheffler, K. Die beteilingung von phenylresten an der aroxylmesomerie. Liebigs Ann. Chem. 689, 78-92(1965).

37) Mukai, K.; Yoshimoto, M.; Ishikura, M.; Nagaoka, S. Kinetic study of the aroxyl-radical-scavenging activity of five fatty acid esters and six carotenoids in toluene solution: Structure-activity relationship for the hydrogen abstraction reaction. J. Phys. Chem. B 121, 7593$7601(2017)$.

38) Mukai, K.; Nagai, S.; Ohara, K. Kinetic study of the quenching rection of singlet oxygen by tea catechins in ethanol solution. Free Radical Biol. Med. 39, 752761 (2005).

39) Krasnovsky Jr, A.A.; Kagan, V.E.; Minin, A.A. Quenching of singlet oxygen luminescence by fatty acids and lipids. Contribution of physical and chemical mechanisms. FEBS Leters 155, 233-236 (1983).

40) Doleiden, F.H.; Fahrenholtz, S.R.; Lamola, A.A; Trozzolo, A.M. Reactivity of cholesterol and some fatty acids toward singlet oxygen. Photochem. Photobiol. 20, 519-521 (1974).

41) Fahrenholts, S.R.; Doleiden, F.H.; Trozzolo, A.M.; Lamola, A.A. On the quenching of singlet oxygen by $\alpha$-tocopherol. Photochem. Photobiol. 20, 505-509 (1974).

42) Foote, C.S.; Ching, T.-Y.; Geller, G.G. Chemistry of singlet oxygen - XVIII. Rates of reaction and quenching of $\alpha$-tocopherol and singlet oxygen. Photochem. Photobiol. 20, 511-513(1974).

43) Tanielian, C.; Mechin, R. Reaction and quenching of singlet molecular oxygen with esters of polyunsaturated fatty acids. Photochem. Photobiol. 59, 263-268 (1994), and references are cited therein.

44) Nagaoka, S.; Okauchi, Y.; Urano, S.; Nagashima, U.; Mukai, K. Kinetic and ab initio study of the prooxidant effect of vitamin E. Hydrogen abstraction from fatty acid esters and egg yolk lecithin. J. Am. Chem. Soc. 112, 8921-8924(1990).

45) Remorova, A.A.; Roginsky, V.A. Rate constants for the reaction of $\alpha$-tocopherol phenoxy radicals with unsaturated fatty acid esters, and the contribution of this reaction to the kinetics of inhibition of lipid oxidation. Kinet. Catal. 32, 726-731(1991).

46) Ouchi, A.; Ishikura, M.; Konishi, K.; Nagaoka, S.; Mukai, K. Kinetic study of the prooxidant effect of $\alpha$-tocopherol. Hydrogen abstraction from lipids by $\alpha$-tocopheoxyl radical. Lipids 44, 935-943(2009), and references are cited therein. 